\title{
An Approach to Determining Nickel, Vanadium and other Metal Concentrations in Crude Oil
}

\author{
I. Sugiyama ${ }^{1 *}$ and A.E. Williams-Jones ${ }^{1}$ \\ ${ }^{1}$ Department of Earth and Planetary Sciences, McGill University, Montreal, QC, Canada \\ *Corresponding author: +1 (514)-883-0058, Ichiko.sugiyama@mail.mcgill.ca
}

\begin{abstract}
The ability to accurately determine the metal content of crude oils is necessary for reasons ranging from the need to identify the source of the oils ( $\mathrm{Ni}$ and $\mathrm{V}$ ) to removing components that might inhibit catalysis during refining or impact negatively on the environment during hydrocarbon combustion. Here we show that ashing followed by chemical oxidation and acid digestion, coupled with ICP-MS analysis, provides an accurate method for determining the concentration of metals in crude oil. Nickel and vanadium concentrations were measured in certified $\mathrm{Ni}$ and $\mathrm{V}$ oil standards and in various light, intermediate and heavy crude oils after application of a single vessel ashing-chemical oxidation-acid digestion sample preparation and storing technique. Prior to the ashing, chemical oxidation and acid digestion, an aliquot of the crude oil was placed in a $10 \mathrm{ml} \mathrm{Pyrex}{ }^{\mathrm{TM}}$ culture tube and capped with quartz wool. The capped culture tubes were then subjected to thermal combustion, followed by chemical oxidation and leaching. The leachates and the aqueous standards were diluted and analyzed for their $\mathrm{Ni}$ and $\mathrm{V}$ contents using inductively coupled plasma mass spectrometry (ICP-MS).
\end{abstract}

The measured concentrations of $\mathrm{Ni}$ in oil standards, reported to contain 1,100 , and $1000 \mathrm{mg} \mathrm{kg}^{-1} \mathrm{Ni}( \pm 2 \%$ error), were $1.1 \pm 0.01,99.8 \pm 1.46$, and $1025 \pm 24 \mathrm{mg} \mathrm{kg}^{-1}$ respectively. The corresponding concentrations of $\mathrm{V}$ in these standards, reported to contain 2,100 , and $1000 \mathrm{mg} \mathrm{kg}^{-1} \mathrm{~V}$, were measured to be $1.93 \pm 0.06,104 \pm 1.3$, and $1027 \pm$ $7.5 \mathrm{mg} \mathrm{kg}^{-1}$, respectively. Crude oil samples, A, B, C, D and E, that varied significantly in their composition, and ranged from light to heavy, were determined to contain $5.59 \pm 0.32,4.05 \pm 0.03,6.22 \pm 0.22,33.8 \pm 0.7$ and $41.6 \pm$ $3.5 \mathrm{mg} \mathrm{kg}^{-1} \mathrm{Ni}$, respectively. Their $\mathrm{V}$ contents were determined to be $11.98 \pm 0.1,12.2 \pm 0.1,16.5 \pm 0.4,34.7 \pm 0.4$, and $104 \pm 8.9 \mathrm{mg} \mathrm{kg}^{-1}$, respectively. The results were thus repeatable on average to $4.1 \%$ and $2.75 \%$ for $\mathrm{Ni}$ and $\mathrm{V}$, respectively; the repeatability was worst $(\sim 8.5 \%)$ for crude oil E, a heavy (viscous) oil with a very high asphaltene content $(27.2 \%)$. 
This modified single vessel ashing-digestion technique (combustion, chemical oxidation, acid leaching and storing) minimizes contamination and significantly reduces the loss of ash. Our results are repeatable, comparable to, and in some cases superior to those of other methods. The method is applicable to a wide range of crude oil compositions, is very accessible and robust, easy to use, and does not require costly equipment in preparing the samples for analysis by ICP-MS.

Keywords: crude oil, nickel, vanadium, ashing, acid digestion, inductively coupled plasma mass spectrometry

\section{Introduction}

Accurate determination of metal concentrations in crude oils to low levels of detection is needed for a variety of reasons. For example, some metals (e.g., Ni, Co, Pd, Pt, and S) may poison catalysts used in refining oils, thereby reducing their effectiveness, some metals (e.g., $\mathrm{Cr}, \mathrm{Fe}, \mathrm{Al}$, and $\mathrm{Cr}$ ) may cause corrosion in oil-fired power plants, whereas other metals (e.g., $\mathrm{Pb}, \mathrm{Hg}, \mathrm{Cr}, \mathrm{Ni}, \mathrm{Cd}$, and $\mathrm{As}$ ), will impact negatively on the environment, if released to the atmosphere (even in low concentrations) during the combustion of petroleum products [1-9]. The two metals that consistently have the highest concentrations in crude oils are $\mathrm{Ni}$ and $\mathrm{V}$ (up to $1000 \mathrm{mg} \mathrm{kg}^{-1}$ and $200 \mathrm{mg} \mathrm{kg}^{-1}$, respectively) [9-11], although their absolute concentrations vary considerably among different crude oils. Because of their high and variable concentrations, these two metals are analyzed routinely in crude oil to identify the source regions and determine the migration paths of the hydrocarbons $[1,2,13,14]$. Analysis for these metals has also proven helpful in evaluating crude oil maturation, because mature oils have lower concentrations of $\mathrm{Ni}$ and $\mathrm{V}$ porphyrins than immature oils, and to assign responsibility in the case of oil spills $[2,6,15,16]$. The current investigation, however, was motivated by a need to be able to analyze crude oils that had been reacted with metals as part of a project designed to test the hypothesis that liquid hydrocarbons might constitute ore fluids for some deposit types.

Metal concentrations in crude oil can be determined either by direct instrumental analysis with little or no sample preparation (refer to Table A.1. in Appendix A in the supplementary material), or with a destructive method of sample preparation that decomposes the oil and is followed by instrumental analysis (refer to Table A.2. in Appendix A in the supplementary material). The former determinations are made with neutron activation analysis (NAA), graphite 
furnace atomic absorption spectrometry (GF-AAS), inductively coupled plasma mass spectrometry (ICP-MS) and inductively coupled plasma optical emission spectrometry (ICP-OES). Only NAA, however, requires no sample preparation. The other three techniques require the crude oils to be diluted (e.g., with xylene or toluene) or emulsified prior to instrumental analysis (refer to Table A.1. in Appendix A in the supplementary material). These techniques are much less time-consuming than the destructive techniques, which generally involve relatively complex sample preparation procedures [e.g. 17,18]. However, the detection limits are higher and the accuracy lower. The lower accuracy is because these techniques require the use of aqueous or oil standards, which have a matrix that is different from the complex matrix of the crude oil sample [19 - 22]. For further discussion of the problems associated with direct analysis of crude oils, readers are referred to the reviews of Filby and Olsen (1994) and Mello et al., (2012).

Destructive sample preparation consists either of chemical oxidation/acid digestion (oxidation and leaching of crude oil with acids, e.g., $\mathrm{HNO}_{3}+\mathrm{HCl}$ ) or a combination of ashing and acid digestion (thermal combustion followed by acid digestion; refer to Table A.2. in Appendix A in the supplementary material). The former preparation typically makes use of a high-pressure asher (HPA; acid digestion using a quartz reactor) [e.g., 22,24], a microwave oven (microwaveinduced acid digestion, MIC; acid digestion using a polytetrafluroethylene (PTFE $\left.{ }^{\mathrm{TM}}\right)$ - $\mathrm{TFM}^{\mathrm{TM}}$ lined reactor) [e.g., 22,24,25], or simply a beaker and a hotplate (ASTM D5708-15) [e.g., 23]. In all three methods, an aliquot of oil is added to a large volume of acid either in a closed (HPA or MIC) or an open vessel (ASTM D5708-15) to destroy the organic matrix and dissolve the associated metals. Although, HPA and MIC yield highly repeatable and reproducible results, the equipment is costly and can be inaccessible, and the number of samples that can be digested per session is relatively small (approximately four quartz vessels for HPA and 12 PTFE $^{\mathrm{TM}}-\mathrm{TFM}^{\mathrm{TM}}$ lined vessels for MIC per session; there are more expensive systems that can digest organic materials in up to 168 samples, e.g., NovaWave but these are not commonly used in research laboratories). Furthermore, although the vessels for MIC and HPA contain safety mechanisms to prevent over-pressurization, if the safety membrane (MIC) or cap (HPA) opens, the acids can spill out of the vessels, thereby creating a risk to safety. The ASTM D5708-15 method, in contrast, is very simple to use, safe and inexpensive. However, as it utilizes an open beaker, there is a high probability of contamination and loss of acid, leading to poor reproducibility of results. 
Combined dry-ashing and acid digestion involves placing an aliquot of the crude oil sample in a platinum (Pt) or quartz crucible and heating it to $\sim 450$ to $550^{\circ} \mathrm{C}$ under a 1 bar oxygen atmosphere [26]. This removes most of the organic matrix [26-28]. Nitric acid or sulfuric acid is then added to the crucible, which serves to oxidize the remaining ash and leach the metals. The digested samples are then diluted for further analysis (e.g., AAS, ICP-MS, and ICPOES). Although this method is simple, safe, and affordable, it has been strongly criticized because of poor metal recovery due to volatilization and loss of ash, the large volume of sample required (up to $20 \mathrm{ml}$ ) and the long preparation time [e.g., 20-22,24,26].

Below, we describe a modification of the combined ashing and chemical oxidation/acid digestion method of preparation, which addresses the above criticisms. In this method, $5 \mathrm{ml}$ crude oil samples are ashed, chemically oxidized, and leached in narrow disposable Pyrex ${ }^{\mathrm{TM}}$ culture tubes capped with quartz wool to prevent material loss (e.g., volatile elements, volatile compounds, or oil) during combustion. This modification reduces the sample size considerably, allows ashing, chemical oxidation, leaching and storage to be done in the same reactor, thereby minimizing the risk of contamination, and greatly increasing the number of samples that can be ashed simultaneously. Most importantly, the modification yields highly reproducible metal concentrations with an accuracy comparable, and in some cases superior, to those that have been reported for other methods.

\section{Material and Methods}

\subsection{Sample Description}

Nickel and vanadium crude oil standards were purchased from the Conostan® division of SCP Science Ltd (refer to Appendix $\mathrm{G}$ for more information). The selected certified oil standards had been analyzed according to the protocol proposed by the American Society of Testing Material (ASTM) D5708 using the appropriate NIST standards. The nickel oil standards have concentrations of $1 \mathrm{mg} \mathrm{kg}^{-1}$ (Conostan Cat. No. CB7-100-002), $100 \mathrm{mg} \mathrm{kg}^{-1}$ (Conostan Cat. No. CB7-100-018) and $1000 \mathrm{mg} \mathrm{kg}^{-1}$ (Conostan Cat. No. CB7-100-019), and the vanadium oil standards have concentrations of $2 \mathrm{mg} \mathrm{kg}^{-1}$ (Conostan Cat. No. CB7-100-024), $100 \mathrm{mg} \mathrm{kg}^{-1}$ (Conostan Cat. No. CB7-100-025) and $1000 \mathrm{mg} \mathrm{kg}^{-1}$ (Conostan Cat. No. CB7-100-026). 
Five crude oils, A, B, C, D and E, were selected to provide a broad range of properties and compositions (Table 1), A being the lightest and $\mathrm{E}$ being the heaviest crude oil based on their respective API gravity. This range of crude oil compositions allowed us to evaluate the effect of crude oil chemistry on the precision.

\subsection{Ashing and Digestion}

Aliquots of the oil standards (approximately $5 \mathrm{~g}$ ) and the crude oils (approximately $5 \mathrm{~g}$ ) were placed in clean disposable $10 \mathrm{ml} \mathrm{Pyrex}{ }^{\mathrm{TM}}$ culture tubes $(100 \mathrm{~mm}$ long with an outer diameter of $13 \mathrm{~mm}$ ) that were stoppered with quartz wool and heated to $550^{\circ} \mathrm{C}$ (Fig. 1). Prior to ashing, the tubes and the wool stoppers were washed using trace metal grade nitric acid $\left(75 \% \mathrm{HNO}_{3}\right)$ for 24 hours, neutralized for two hours with ultrapure water (Mili-Q® Integral water purification system), and dried in an oven at $100^{\circ} \mathrm{C}$ for one hour. Four separate aliquots of samples of each oil standard $(\sim 5 \mathrm{~g})$ and crude oil $(\sim 5 \mathrm{~g})$ were prepared for ashing and analysis (the heavy crude oil sample was heated to approximately $80^{\circ} \mathrm{C}$ and agitated prior to preparation for ashing to ensure homogeneity). Each tube was stoppered with compressed quartz wool, placed in a Thermolyne ${ }^{\mathrm{TM}}$ muffle oven and heated at $550{ }^{\circ} \mathrm{C}$ for 12 hours (up to 36 tubes can be ashed simultaneously using this particular model of oven). Commonly, traces of ash were visible at the bottom of the tubes after they had been removed from the oven. In order to ensure complete decomposition of the ash, four $\mathrm{ml}$ of trace metal grade nitric acid $\left(75 \% \mathrm{HNO}_{3}\right)$, and one $\mathrm{ml}$ of optima grade hydrogen peroxide $\left(30 \% \mathrm{H}_{2} \mathrm{O}_{2}\right)$ were added to the Pyrex ${ }^{\mathrm{TM}}$ tubes. After decomposition of the residual ash, one $\mathrm{ml}$ of trace metal grade hydrochloric acid $(36 \% \mathrm{HCl})$ was added to the vessels to dissolve any metallic precipitates. The sample tube was then tightly capped (a screw cap for Pyrex ${ }^{\mathrm{TM}}$ culture tubes with PTFE liners) and the leachate stored until analysis by ICP-MS (usually the following day).

\subsection{ICP-MS Analysis}

The nickel $\left({ }^{60} \mathrm{Ni}\right)$, vanadium $\left({ }^{51} \mathrm{~V}\right)$ and yttrium $\left({ }^{89} \mathrm{Y}\right)$ counts for the diluted digested acid samples (oil standards and crude oils), the $0.5,1,5,10,15,20$ and $50 \mathrm{mg} \mathrm{g}^{-1} \mathrm{Ni}$ and $\mathrm{V}$ aqueous standards (standards purchased from SCP Science Ltd.) and the blank solution ( $1 \mathrm{mg} \mathrm{g}^{-1} \mathrm{Y}$ in ultrapure water) were measured using a Thermo Scientific ${ }^{\mathrm{TM}}$ iCAP $^{\mathrm{TM}} \mathrm{Q}$ ICP-MS (conditions listed in Table 2). All calibration curves regressed linearly through the origin with a goodness of fit of $99.9 \%$. The instrumental detection limit (IDL) for Ni and V using the ICP-MS was 0.005 and $0.006 \mu \mathrm{kg}^{-1}$, 
respectively. Refer to Appendix B for further details on the dilution of samples and standards, and the data reduction (e.g., ${ }^{60} \mathrm{Ni}$, and ${ }^{51} \mathrm{~V}$ counts to concentrations).

\section{Results}

\subsection{Nickel and Vanadium Oil Standards: Validation of the Method}

Certified nickel and vanadium oil standards with concentrations of 1,100 , and $1000 \mathrm{mg} \mathrm{kg}^{-1}$ for Ni and 2, 100, and $1000 \mathrm{mg} \mathrm{kg}^{-1}$ for $\mathrm{V}$ were ashed, chemically oxidized, digested and analyzed in quadruplicate $(\mathrm{n}=4)$ to test the reliability of the analytical method. The analyses for the 1,100 , and $1000 \mathrm{mg} \mathrm{kg}^{-1} \mathrm{Ni}$ standards yielded concentrations of $1.1 \pm$ $0.01,99.8 \pm 1.46$, and $1025 \pm 24 \mathrm{mg} \mathrm{kg}^{-1}$, respectively (Table 3). In comparison, the standards with 2, 100, and 1000 $\mathrm{mg} \mathrm{kg}{ }^{-1} \mathrm{~V}$, yielded concentrations of $1.93 \pm 0.06,104 \pm 1.3$, and $1027 \pm 7.5 \mathrm{mg} \mathrm{kg}^{-1}$, respectively (Table 3; Fig. 2). Thus, the combined ashing-chemical oxidation-acid digestion sample preparation method used in conjunction with ICP-MS analysis reproduced the reported concentrations of $\mathrm{Ni}$ and $\mathrm{V}$ in the certified $1 \mathrm{mg} \mathrm{kg}^{-1}$ standards to an accuracy of $90 \%$ and $97 \%$, respectively, the $100 \mathrm{mg} \mathrm{kg}^{-1}$ standards to an accuracy of $\pm 100 \%$ and $96 \%$, respectively, and the $1000 \mathrm{mg} \mathrm{kg}^{-1}$ standards to an accuracy of $98 \%$ and 97\%, respectively (Table 3; Fig. 2). For the higher concentrations, the errors are comparable to those reported by Conostan. Furthermore, the linearity $(n=12$ per metal of interest) (i.e., the linear regression of observed trace metal concentration vs. expected concentration of crude oil standard) for $\mathrm{Ni}$ and $\mathrm{V}$ regressed to $\mathrm{r}^{2}$ value of $99.9 \%$ and $100 \%$, respectively, and the slopes were 1.025 and 1.027 , respectively (Figure 2; see appendix $\mathrm{F}$ for more information). This provides confidence that the analytical method described here can be used reliably to determine the $\mathrm{Ni}$ and $\mathrm{V}$ contents of crude oils. For further discussion of the results of the analyses of the Ni and V oil standards, refer to section 4.1.

\subsection{Nickel and Vanadium in Crude Oils}

The nickel and vanadium concentrations of the five crude oils were also determined in quadruplicate analyses. The concentrations of $\mathrm{Ni}$ in crude oils, A, B, C, D and E were determined to be $5.59 \pm 0.32,4.05 \pm 0.03,6.22 \pm 0.22,33.8$ \pm 0.7 and $41.6 \pm 3.5 \mathrm{mg} \mathrm{kg}^{-1}$, respectively, and those for $\mathrm{V}$ to be $11.98 \pm 0.1,12.2 \pm 0.1,16.5 \pm 0.4,34.7 \pm 0.4$, and $104 \pm 8.9 \mathrm{mg} \mathrm{kg}^{-1}$, respectively (Fig. 3; Tables 4 and 5). These results correspond to Ni concentrations that are repeatable to $5.7 \%$ and $0.7 \%$ for light oils A, and B, respectively, $3.5 \%$ and $1.9 \%$ for intermediate oils C and D, respectively and $8.4 \%$ for the heavy oil, E. The repeatability for $\mathrm{V}$ is $0.8 \%$ and $1.6 \%$ for oils A and B, respectively, 
$2.4 \%$ and $1.2 \%$ for oils $\mathrm{C}$ and $\mathrm{D}$, respectively and $8.6 \%$ for oil $\mathrm{E}$. The analytical method is thus very reliable for a wide range of oil types and metal concentrations. For further discussion of these results, refer to section 4.2.

\section{Discussion}

\subsection{Reproducibility and the Advantages of the Modified Ashing Technique}

As will be shown below, our modified ashing-chemical oxidation-acid digestion-ICP-MS method of analysis of metals in crude oil yields results that are considerably more repeatable and have a much higher accuracy than the dry-ashing technique of Horeczy et al. (1955), and the modern dry-ashing technique (IP501) commonly used in the petroleum industry. The method developed by Horeczy et al. (1955) measured Ni and V concentrations in a gasoline blend containing known amounts of these metals (nickel and vanadium tetraphenylporphyrins) using ashing followed by emission spectrograph analysis. Their method of ashing involved combusting the blend in a wide, shallow platinum (Pt) crucible placed in a muffle furnace oven. This analysis underestimated the true concentrations of the metals by 54 and $88 \%$, respectively, in large part, due likely to volatilization and loss of sample during ashing. In the IP501 method, 20 - 50 g samples are combusted in a Pt crucible that is initially warmed using a Bunsen flame and then placed in a muffle oven. A flux comprising $90 \%$ dilithium tetraborate and $10 \%$ lithium fluoride and an ashing agent (99.9\% sulfur) are added to the crucible to assist in the combustion of the ash. After ashing, the residues are digested with a tartaric acid/hydrochloric acid mixture $(50 \mathrm{ml})$ on a hot plate. The acid mixture is then placed in a $100 \mathrm{ml}$ beaker, filled to the top with water, and stored for ICP-OES analyses. This method shows poor reproducibility and repeatability for metal concentrations below $100 \mathrm{mg} \mathrm{kg}^{-1}$, and even for concentrations above $100 \mathrm{mg} \mathrm{kg}^{-1}$ the reproducibility is inferior to that of other methods (e.g., current study, HPA and MIC). The reasons for the poor reproducibility are not known but may include the fact that the ashing is carried out in an open crucible and that the process is relatively complex, involving multiple steps, numerous reagents and separate reaction and storage containers. Our modification of the ashing-acid digestion method, namely replacing the Pt crucibles with slender disposable Pyrex ${ }^{\mathrm{TM}}$ culture tubes stoppered with quartz wool, prevents the loss of oil and ash during the release of gases produced by combustion, and therefore maximizes the recovery of the metals. Furthermore, our method uses a single vessel to ash, chemically oxidize, leach and store the samples, as well as a simple reagent protocol, thereby reducing the potential for contamination. 
To further evaluate the reliability of our modified ashing-chemical oxidation-acid digestion-ICP-MS method of crude oil analysis, we compared the accuracy, precision, and limit of detection (LOD) of our analyses to those obtained using other techniques (for accuracy and precision, see Table 6; for LOD, see Table 7). Our modified technique has a level of accuracy and precision comparable to the HPA-ICP-MS and the MIC-ICP-OES techniques, returning concentrations of $99.8 \pm 1.5$ and $104 \pm 1.3 \mathrm{mg} \mathrm{kg}^{-1}$, respectively, for $100 \mathrm{mg} \mathrm{kg}^{-1}$ crude oil Ni and V standards (Fig. 4). By contrast, direct analysis with ICP-MS (toluene dilution) underestimates the Ni and V contents of oil standards by $11.4 \%$ and $8.5 \%$, respectively; direct analysis with ICP-MS (emulsification) underestimates them by $6.9 \%$ and 3.5\%, respectively; direct analysis with ICP-OES (ASTM D5708) underestimates them by 13 and 10\%, respectively; direct analysis with INAA underestimates them by $17.3 \%$ and $4.2 \%$, respectively; and dry ashing-acid digestion (IP 501) underestimates them by up to 84 and $80 \%$ (for $1 \mathrm{mg} \mathrm{kg}^{-1}$ ), respectively (Fig. 4). Thus, our technique has a precision and accuracy comparable to the highest of any of the other techniques referred to in Table 6. Furthermore, the LOD (Table 7) is comparable to that of Duyck et al., (2002), and superior to that for some other methods (no information on the LOD was provided by Horeczy et al., 1955, and Ortega et al., 2013). An important observation is that our method is not only reproducible, but also applicable to a wider range of concentrations than many other methods, and is also excellent for measuring very low $\mathrm{Ni}$ and $\mathrm{V}$ concentrations (see Appendix $\mathrm{F}$ for further details on the LOD and a summary of the method of validation employed in our current study). In summary, the ashing-chemical oxidation-acid digestion-ICP-MS method of determining metal concentrations in crude oil described in this paper is simple, accessible, reliable, affordable, and generates very accurate and precise results for a wide range of $\mathrm{Ni}$ and $\mathrm{V}$ concentrations.

\subsection{Reproducibility of Measured Nickel and Vanadium Concentrations in Crude Oils}

Although the Ni and V contents of crude oils A to E were reliably analyzed using the modified ashing-ICP-MS technique described in this paper, the precision was significantly better for the light and intermediate crude oils than the heavy crude oil (Tables 4 and 5). The heavy crude oil (E) is the most viscous of the crude oils analyzed, with a tar-like consistency. It is thus very likely that it was less homogeneous than the other crude oils due probably to the presence of solid hydrocarbons, notably asphaltenes (crude oil E contains $27.2 \mathrm{wt} . \%$ asphaltenes) [30]. In principle, because inhomogeneity will increase with decreasing sample size, this problem could be mitigated by analyzing larger, mechanically mixed, samples. However, this was not attempted as the $92 \%$ precision achieved, was deemed acceptable. 
In summary, our ashing-chemical oxidation-acid digestion-ICP-MS technique can be used to measure metal concentrations in a variety of crude oils with considerable accuracy and precision.

\section{Conclusion}

The analytical method described in this paper provides a simple, easily accessible, and affordable method for determining metal concentrations in crude oil. The results obtained using it to analyze the $\mathrm{Ni}$ and $\mathrm{V}$ contents of a selection of oil standards are in excellent agreement with the certified values, and demonstrate that the modifications introduced in the method of sample preparation have successfully addressed criticisms that ashing and acid digestion cannot be used reliably in analyses of crude oil. Indeed, the accuracy and precision of the analyses presented in this study compare very favorably with those obtained involving other more expensive and less accessible methods of sample preparation and/or analysis, and in several cases are superior to them. Thus the method developed in this study, which involves a combination of ashing, chemical oxidation and acid digestion followed by ICP-MS analysis provides an effective means for reliably determining the metal concentrations of crude oils in any laboratory equipped with an ICP-MS and an oven.

\section{Acknowledgements}

This study would not have been possible without the help of Anna Jung and Vincent van Hinsberg in using the ICPMS. Financial support for the study was provided by a NSERC Collaborative Research and Development grant to AEW-J. The manuscript benefitted from thoughtful reviews by two anonymous referees.

\section{References}

[1] Akinlua, A., \& Torto, N. (2006). Determination of selected metals in Niger Delta Oils by graphite furnace atomic absorption spectrometry. Analytical letters, 39(9), 1993-2005.

[2] Al-Shahristani, H., \& Al-Atyia, M. J. (1972). Vertical migration of oil in Iraqi oil fields: Evidence based on vanadium and nickel concentrations. Geochimica et Cosmochimica Acta, 36(9), 929-938.

[3] Amorim, F. A., Welz, B., Costa, A. C., Lepri, F. G., Vale, M. G. R., \& Ferreira, S. L. (2007). Determination of vanadium in petroleum and petroleum products using atomic spectrometric techniques. Talanta, 72(2), 349359. 
[4] Aucelio, R. Q., de Souza, R. M., de Campos, R. C., Miekeley, N., \& da Silveira, C. L. P. (2007). The determination of trace metals in lubricating oils by atomic spectrometry. Spectrochimica Acta Part B: Atomic Spectroscopy, 62(9), 952-961.

[5] Bettmer, J., Heilmann, J., Kutscher, D. J., Sanz-Medel, A., \& Heumann, K. G. (2012). Direct $\mu$-flow injection isotope dilution ICP-MS for the determination of heavy metals in oil samples. Analytical and bioanalytical chemistry, 402(1), 269-275.

[6] Erdman, J. G., \& Harju, P. H. (1963). Capacity of Petroleum Asphaltenes to Complex Heavy Metals. Journal of Chemical and Engineering Data, 8(2), 252-258.

[7] Quadros, D. P., Chaves, E. S., Lepri, F. G., Borges, D. L., Welz, B., Becker-Ross, H., \& Curtius, A. J. (2010). Evaluation of Brazilian and Venezuelan crude oil samples by means of the simultaneous determination of $\mathrm{Ni}$ and $\mathrm{V}$ as their total and non-volatile fractions using high-resolution continuum source graphite furnace atomic absorption spectrometry. Energy \& Fuels, 24(11), 5907-5911.

[8] de Souza, R. M., Meliande, A. L., da Silveira, C. L., \& Aucélio, R. Q. (2006). Determination of Mo, Zn, Cd, Ti, $\mathrm{Ni}, \mathrm{V}, \mathrm{Fe}, \mathrm{Mn}, \mathrm{Cr}$ and $\mathrm{Co}$ in crude oil using inductively coupled plasma optical emission spectrometry and sample introduction as detergentless microemulsions. Microchemical Journal, 82(2), 137-141.

[9] Mello, P. A. et al. Nickel, vanadium and sulfur determination by inductively coupled plasma optical emission spectrometry in crude oil distillation residues after microwave-induced combustion. Journal of Analytical Atomic Spectrometry, v. 24, p. 911-916, 2009.

[10] Barwise, A. J. G. (1990). Role of nickel and vanadium in petroleum classification. Energy \& Fuels, 4(6), 647652.

[11] Jones, P. (Ed.). (1975). Trace metals and other elements in crude oil: a literature review. British Petroleum Co. Ltd.

[12] Manning, D. A., \& Gize, A. P. (1993). The role of organic matter in ore transport processes. In Organic Geochemistry (pp. 547-563). Springer US.

[13] Lewan, M. D. (1984). Factors controlling the proportionality of vanadium to nickel in crude oils. Geochimica et Cosmochimica Acta, 48(11), 2231-2238.

[14] Shah, K. R., Filby, R. H., \& Haller, W. A. (1970). Determination of trace elements in petroleum by neutron activation analysis. Journal of Radioanalytical Chemistry, 6(2), 413-422.

Sugiyama, I. and A. E. Williams-Jones. "An Approach to Determining Nickel, Vanadium and Other Metal 
[15] McKenna, A. M., Purcell, J. M., Rodgers, R. P., \& Marshall, A. G. (2009). Identification of vanadyl porphyrins in a heavy crude oil and raw asphaltene by atmospheric pressure photoionization Fourier transform ion cyclotron resonance (FT-ICR) mass spectrometry. Energy \& Fuels, 23(4), 2122-2128.

[16] Shen, J., Engen, R. J., \& Saadeh, N. K. (1985). Identification of Spilled Crude Oils from Similar Origins. Arabian for Science and Engineering, 10(1), 63-78.

[17] Murillo, M., \& Chirinos, J. (1994). Use of emulsion systems for the determination of sulfur, nickel and vanadium in heavy crude oil samples by inductively coupled plasma atomic emission spectrometry. Journal of Analytical Atomic Spectrometry, 9(3), 237-240.

[18] Duyck, C., Miekeley, N., da Silveira, C. L. P., \& Szatmari, P. (2002). Trace element determination in crude oil and its fractions by inductively coupled plasma mass spectrometry using ultrasonic nebulization of toluene solutions. Spectrochimica Acta Part B: Atomic Spectroscopy, 57(12), 1979-1990.

[19] Filby, R., \& Olsen, S. (1994). A comparison of instrumental Neutron Activation Analysis and inductively coupled plasma mass spectrometry for trace element determination in petroleum geochemistry. Journal of radioanalytical and nuclear chemistry, 180(2), 285-294.

[20] Hardaway, C., Sneddon, J., \& Beck, J. N. (2004). Determination of metals in crude oil by atomic spectroscopy. Analytical letters, 37(14), 2881-2899.

[21] Fischer, J. L., \& Krusberski, N. B. (2005). An evaluation of emulsions in wear-metal-in-oil analyses. South African Journal of Chemistry, 58, 131-137.

[22] Mello, P. A., Pereira, J. S., Mesko, M. F., Barin, J. S., \& Flores, E. M. (2012). Sample preparation methods for subsequent determination of metals and non-metals in crude oil-A review. Analytica chimica acta, 746, 1536.

[23] ASTM Standard D5708, 2005e15, " Standard Test Methods for Determination of nickel, vanadium, and iron in Crude Oils and Residual Fuels by inductively coupled plasma atomic emission spectrometry," ASTM International, West Conshohocken, PA, 2005.

[24] Ortega, G. S., Pécheyran, C., Hudin, G., Marosits, E., \& Donard, O. F. (2013). Different approaches of crude oil mineralisation for trace metal analysis by ICPMS. Microchemical Journal, 106, 250-254.

[25] Saydut, A. (2010). Microwave acid digestion for the determination of metals in subbitumnious coal bottom ash by ICP-OES. Energy Exploration \& Exploitation, 28(2), 105-115. 
[26] Barin, J. S., Flores, E. M. M., \& Knapp, G. (2006). Trends in sample preparation using combustion techniques. Trends in Sample Preparation, Nova Science Publishers, Hauppauge, 73-114.

[27] Horeczy, J. T., Hill, B. N., Walters, A. E., Schutze, H. G., \& Bonner, W. H. (1955). Determination of trace metals in oils. Analytical Chemistry, 27(12), 1899-1903.

[28] EI-IP, 501-2005. Determination of aluminium, silicon, vanadium, nickel, iron, sodium, calcium, zinc and phosphorus in residual fuel oil by ashing, fusion and inductively coupled plasma emission spectrometry.

[29] Thomas, R. (2013). Practical guide to ICP-MS: a tutorial for beginners. CRC press.

[30] Yin, C. X., Tan, X., Müllen, K., Stryker, J. M., \& Gray, M. R. (2008). Associative $\pi-\pi$ Interactions of condensed aromatic compounds with vanadyl or nickel porphyrin complexes are not observed in the organic phase. Energy \& Fuels, 22(4), 2465-2469. 
Table 1. Properties of, and compositional information for, the five natural crude oil samples employed in this study. Crude oils A to E are ordered from the lightest to heaviest based on their specific gravity (API).

\begin{tabular}{|c|c|c|c|c|c|}
\hline Parameters & $\mathbf{A}$ & B & $\mathbf{C}$ & D & $\mathbf{E}$ \\
\hline API Gravity & 26.6 & 25.0 & 19.0 & 13.4 & 8.5 \\
\hline Specific Gravity & 0.895 & 0.904 & 0.940 & 0.976 & 1.011 \\
\hline Sulfur (wt\%) & 0.84 & 0.52 & 0.82 & 1.89 & 4.98 \\
\hline Nitrogen (wt\%) & - & 0.20 & 0.44 & 0.92 & 0.56 \\
\hline TAN (mgKOH/g) & 0.2 & 2.9 & 2.3 & 0.92 & 2.7 \\
\hline Paraffins (vol\%) & - & 36.99 & 18.81 & 59.8 & 53.0 \\
\hline Naphthenes (vol\%) & - & 49.35 & 64.88 & 30.3 & 36.7 \\
\hline Aromatics (vol\%) & - & 13.36 & 14.95 & 10.0 & 10.2 \\
\hline Asphaltenes (wt\%) & 1.6 & 0.3 & 1.4 & 18.6 & 27.2 \\
\hline
\end{tabular}


Table 2. Conditions employed in using the ICP-MS to determine metal concentrations in diluted samples.

\section{ICP-MS Parameters}

$\begin{array}{lc}\text { Plasma power }(\mathbf{W}) & 1548 \\ \text { Plasma Ar gas flow }\left(\mathbf{l} \text { min }^{-1}\right) & 15 \\ \text { Auxiliary flow }\left(\mathbf{l} \text { min }^{-1}\right) & 0.8 \\ \text { Nebulizer } & \text { PFA-ST } \\ \text { Nebulizer flow }\left(\mathbf{l} \text { min }^{-1}\right) & 1.11 \\ \text { Spray chamber } & \text { PFA Cyclonic } \\ \text { Peltier cooling temperature }\left({ }^{\circ} \mathbf{C}\right) & 2.7 \\ \text { Sample and skimmer cones } & \mathrm{Ni} \\ \text { Plasma cooling water flow }\left(\mathbf{l} \text { min }^{-1}\right) & 3.32 \\ \text { Peristaltic pump speed }(\mathbf{r p m}) & 20 \\ \text { Isotopes measured } & { }^{60} \mathrm{Ni},{ }^{51} \mathrm{~V},{ }^{89} \mathrm{Y} \\ \text { Settling time (s) } & 60 \\ \text { Dwell time (s) } & 60 \\ \text { Total acquisition time (s) } & 120\end{array}$


Table 3. Certified $\mathrm{Ni}$ and V concentrations in oil standards supplied by Conostan $( \pm 2 \%)$, and the Ni and V concentrations of these standards determined using the modified ashing-acid digestion-ICP-MS technique developed during the course of this study.

\begin{tabular}{|c|c|c|c|}
\hline Ni Oil standards $\left(\mathrm{mg} \mathrm{kg}^{-1}\right)$ & Analyzed Ni Contents (mg kg-1) & V Oil standards $\left(\mathrm{mg} \mathrm{kg}^{-1}\right)$ & Analyzed V Contents $\left(\mathrm{mg} \mathrm{kg}^{-1}\right)$ \\
\hline 1 & 1.11 & 2 & 1.99 \\
\hline 1 & 1.12 & 2 & 1.89 \\
\hline 1 & 1.11 & 2 & 1.89 \\
\hline 1 & 1.09 & 2 & 1.96 \\
\hline Average $\left(\mathrm{mg} \mathrm{kg}^{-1}\right)$ & 1.11 & Average $\left(\mathrm{mg} \mathrm{kg}^{-1}\right)$ & 1.93 \\
\hline Standard deviation $\left(\mathrm{mg} \mathrm{kg}^{-1}\right)$ & 0.010 & Standard deviation $\left(\mathrm{mg} \mathrm{kg}^{-1}\right)$ & 0.06 \\
\hline Percent error $(\%)$ & 0.9 & Percent error $(\%)$ & 3.1 \\
\hline 100 & 98.6 & 100 & 106 \\
\hline 100 & 101 & 100 & 105 \\
\hline 100 & 98.5 & 100 & 104 \\
\hline 100 & 101 & 100 & 103 \\
\hline Average $\left(\mathrm{mg} \mathrm{kg}^{-1}\right)$ & 100 & Average $\left(\mathrm{mg} \mathrm{kg}^{-1}\right)$ & 104 \\
\hline Standard deviation (mg kg $\mathbf{~ g ~}^{-1}$ ) & 1.5 & Standard deviation $\left(\mathrm{mg} \mathrm{kg}^{-1}\right)$ & 1.3 \\
\hline Percent error $(\%)$ & 1.5 & Percent error $(\%)$ & 1.3 \\
\hline 1000 & 1027 & 1000 & 1018 \\
\hline 1000 & 1057 & 1000 & 1028 \\
\hline 1000 & 1017 & 1000 & 1037 \\
\hline 1000 & 1001 & 1000 & 1025 \\
\hline Average $\left(\mathrm{mg} \mathrm{kg}^{-1}\right)$ & 1025 & Average $\left(\mathrm{mg} \mathrm{kg}^{-1}\right)$ & 1027 \\
\hline Standard deviation $\left(\mathrm{mg} \mathrm{kg}^{-1}\right)$ & 24 & Standard deviation $\left(\mathrm{mg} \mathrm{kg}^{-1}\right)$ & 7.9 \\
\hline Percent error $(\%)$ & 2.3 & Percent error $(\%)$ & 0.8 \\
\hline
\end{tabular}


Table 4. The nickel concentration of crude oils A, B, C, D, and E determined using the modified ashing-acid digestion ICP-MS analytical method described in this study.

\begin{tabular}{cccccc}
$\begin{array}{c}\text { API Gravity } \\
\text { Name }\end{array}$ & $\begin{array}{c}\mathbf{2 6 . 6} \\
\mathbf{A}\left(\mathbf{m g ~ k g}^{-1}\right)\end{array}$ & $\begin{array}{c}\mathbf{2 5 . 0} \\
\mathbf{B}\left(\mathbf{m g ~ k g}^{-1}\right)\end{array}$ & $\begin{array}{c}\mathbf{1 9 . 0} \\
\mathbf{C}\left(\mathbf{m g ~ k g}^{-1}\right)\end{array}$ & $\begin{array}{c}\mathbf{1 3 . 4} \\
\mathbf{D}\left(\mathbf{m g ~ k g}^{-1}\right)\end{array}$ & $\begin{array}{c}\mathbf{8 . 5} \\
\mathbf{E}\left(\mathbf{m g ~ k g}^{-1}\right)\end{array}$ \\
\hline Sample 1 & 5.59 & 4.01 & 6.52 & 34.21 & 41.66 \\
Sample 2 & 5.32 & 4.09 & 6.13 & 33.20 & 37.81 \\
Sample 3 & 5.41 & 4.05 & 6.00 & 33.30 & 46.26 \\
Sample 4 & 6.03 & 4.04 & 6.24 & 34.50 & 40.78 \\
\hline Average (mg kg-1) & 5.59 & 4.05 & 6.22 & 33.80 & 41.63 \\
Standard Deviation (mg kg $\left.\mathbf{~}^{-1}\right)$ & 0.32 & 0.03 & 0.22 & 0.65 & 3.50 \\
Percent error (\%) & 5 & 1 & 4 & 2 & 8
\end{tabular}

Table 5. The vanadium concentration of crude oils A, B, C, D, and E determined using the modified ashing-acid digestion ICP-MS analytical method described in this study.

\begin{tabular}{|c|c|c|c|c|c|}
\hline $\begin{array}{c}\text { API Gravity } \\
\text { Name }\end{array}$ & $\begin{array}{c}26.6 \\
\mathrm{~A}\left(\mathrm{mg} \mathrm{kg}^{-1}\right)\end{array}$ & $\begin{array}{c}25.0 \\
\text { B }\left(\mathrm{mg} \mathrm{kg}^{-1}\right)\end{array}$ & $\begin{array}{c}19.0 \\
C\left(\mathrm{mg} \mathrm{kg}^{-1}\right)\end{array}$ & $\begin{array}{c}13.4 \\
\text { D }\left(\mathrm{mg} \mathrm{kg}^{-1}\right)\end{array}$ & $\begin{array}{c}8.5 \\
\text { E }\left(\mathrm{mg} \mathrm{kg}^{-1}\right)\end{array}$ \\
\hline Sample 1 & 12.1 & 12.2 & 16.4 & 34.7 & 104 \\
\hline Sample 2 & 12.0 & 12.4 & 16.2 & 34.3 & 93 \\
\hline Sample 3 & 12.0 & 12.3 & 16.2 & 34.5 & 115 \\
\hline Sample 4 & 11.8 & 12.0 & 17.0 & 35.2 & 103 \\
\hline Average (mg kg ${ }^{-1}$ ) & 12.0 & 12.2 & 16.5 & 34.7 & 104 \\
\hline Standard Deviation (mg kg-1) & 0.1 & 0.2 & 0.4 & 0.4 & 8.9 \\
\hline Percent error $(\%)$ & 1 & 1 & 2 & 1 & 9 \\
\hline
\end{tabular}


Table 6. Comparison of the accuracy and precision of different analytical methods used to measure the concentrations of $\mathrm{Ni}$ and $\mathrm{V}$ in crude oil standards.

\begin{tabular}{|c|c|c|c|c|c|c|c|}
\hline Method & $\begin{array}{c}\text { Standard } \\
\text { Matrix }\end{array}$ & Metal & $\begin{array}{c}\text { Standard Value } \\
\left(\mathrm{mg} \mathrm{kg}^{-1}\right)\end{array}$ & $\begin{array}{c}\text { Measured Value } \\
\left(\mathrm{mg} \mathrm{kg}^{-1}\right)\end{array}$ & $\begin{array}{c}\text { Precision } \\
(\%)\end{array}$ & $\begin{array}{c}\text { Accuracy } \\
(\%)\end{array}$ & Reference \\
\hline \multirow{6}{*}{$\begin{array}{l}\text { Dry Ashing } \\
\text { followed by } \\
\text { ICP-MS }\end{array}$} & \multirow{6}{*}{ Crude Oil } & $\mathbf{N i}$ & 1 & $1.1 \pm 0.01$ & 99 & 90 & \multirow{6}{*}{$\begin{array}{l}\text { Current } \\
\text { Study }\end{array}$} \\
\hline & & $\mathbf{N i}$ & 100 & $99.8 \pm 1.46$ & 99 & 100 & \\
\hline & & $\mathbf{N i}$ & 1000 & $1025 \pm 24$ & 98 & 98 & \\
\hline & & $\mathbf{v}$ & 2 & $1.93 \pm 0.06$ & 97 & 97 & \\
\hline & & $\mathbf{V}$ & 100 & $104 \pm 1.3$ & 99 & 96 & \\
\hline & & $\mathbf{V}$ & 1000 & $1027 \pm 7.5$ & 99 & 97 & \\
\hline \multirow{2}{*}{$\begin{array}{l}\text { Dry ashing } \\
\text { followed by } \\
\text { Emission } \\
\text { Spectrograph }\end{array}$} & \multirow{2}{*}{$\begin{array}{l}\text { Gasoline } \\
\text { blend }\end{array}$} & $\mathbf{N i}$ & 15.62 & $8.47 \pm 0.25$ & 97 & 46 & \multirow{2}{*}{$\begin{array}{l}\text { Horeczy } \\
\text { et al. } \\
\text { (1955) }\end{array}$} \\
\hline & & $\mathbf{V}$ & 12.44 & $11 \pm 0.1$ & 99 & 12 & \\
\hline \multirow{6}{*}{$\begin{array}{l}\text { Dry-ashing } \\
\text { followed by } \\
\text { ICP-OES }\end{array}$} & \multirow{6}{*}{$\begin{array}{l}\text { Aqueous } \\
\text { Standard }\end{array}$} & $\mathbf{N i}$ & 1 & $1 \pm 0.61 *$ & 70 & 39 & \multirow{6}{*}{ IP501 } \\
\hline & & $\mathbf{N i}$ & 10 & $10 \pm 2.2 *$ & 89 & 78 & \\
\hline & & $\mathbf{N i}$ & 100 & $100 \pm 7.6^{*}$ & 96 & 92 & \\
\hline & & $\mathbf{V}$ & 1 & $1 \pm 0.61^{*}$ & 77 & 39 & \\
\hline & & $\mathbf{V}$ & 10 & $10 \pm 2.42 *$ & 90 & 75 & \\
\hline & & $\mathbf{V}$ & 100 & $100 \pm 9.6^{*}$ & 96 & 90 & \\
\hline \multirow{4}{*}{$\begin{array}{c}\text { Direct Analysis } \\
\text { with ICP-OES } \\
\text { (Xylene } \\
\text { dilution) }\end{array}$} & \multirow{4}{*}{$\begin{array}{l}\text { Organo- } \\
\text { metallic } \\
\text { Standard }\end{array}$} & $\mathbf{N i}$ & 10 & $10 \pm 0.91 *$ & 99 & 91 & \multirow{4}{*}{$\begin{array}{l}\text { ASTM } \\
\text { D5708 }\end{array}$} \\
\hline & & $\mathbf{N i}$ & 100 & $100 \pm 5.4^{*}$ & 98 & 95 & \\
\hline & & $\mathbf{v}$ & 50 & $50 \pm 3.2 *$ & 98 & 94 & \\
\hline & & $\mathbf{V}$ & 500 & $500 \pm 40^{*}$ & 98 & 92 & \\
\hline \multirow{2}{*}{$\begin{array}{l}\text { Direct Analysis } \\
\text { with ICP-MS } \\
\text { (Toluene } \\
\text { Dilution) }\end{array}$} & \multirow{2}{*}{ Crude Oil } & $\mathbf{N i}$ & $17.5 \pm 0.2$ & $15.5 \pm 0.5$ & 97 & 89 & \multirow{2}{*}{$\begin{array}{l}\text { Duyck et } \\
\text { al. (2002) }\end{array}$} \\
\hline & & $\mathbf{V}$ & $28.2 \pm 0.4$ & $25.8 \pm 0.6$ & 98 & 92 & \\
\hline \multirow{2}{*}{$\begin{array}{l}\text { Direct Analysis } \\
\text { with ICP-MS } \\
\text { (Emuslification) }\end{array}$} & \multirow{2}{*}{ Crude Oil } & $\mathbf{N i}$ & $29 \pm 1$ & $27 \pm 2$ & 93 & 93 & \multirow{2}{*}{$\begin{array}{c}\text { Murillo } \\
\text { and } \\
\text { Chirinos } \\
\text { (1994) }\end{array}$} \\
\hline & & $\mathbf{v}$ & $56 \pm 2$ & $54 \pm 2$ & 96 & 96 & \\
\hline \multirow{2}{*}{$\begin{array}{l}\text { Direct Analysis } \\
\text { with INAA }\end{array}$} & \multirow{2}{*}{ Crude Oil } & $\mathbf{N i}$ & $120 \pm 6$ & $99.2 \pm 5.1$ & 95 & 80 & \multirow{2}{*}{$\begin{array}{l}\text { Filby and } \\
\text { Olsen } \\
(1994)\end{array}$} \\
\hline & & $\mathbf{v}$ & $398 \pm 19.9$ & $381 \pm 23$ & 94 & 96 & \\
\hline \multirow{4}{*}{$\begin{array}{c}\text { Acid Digestion } \\
\text { (open beaker) } \\
\text { followed by } \\
\text { ICP-OES }\end{array}$} & \multirow{4}{*}{$\begin{array}{l}\text { Aqueous } \\
\text { Standard }\end{array}$} & $\mathbf{N i}$ & 10 & $10 \pm 0.36^{*}$ & 98 & 96 & \multirow{4}{*}{$\begin{array}{l}\text { ASTM } \\
\text { D5708 }\end{array}$} \\
\hline & & $\mathbf{N i}$ & 100 & $100 \pm 7.2^{*}$ & 98 & 93 & \\
\hline & & $\mathbf{V}$ & 50 & $50 \pm 2.7 *$ & 98 & 95 & \\
\hline & & $\mathbf{V}$ & 500 & $500 \pm 34^{*}$ & 98 & 93 & \\
\hline \multirow{2}{*}{$\begin{array}{l}\text { MIC followed } \\
\text { by ICP-OES }\end{array}$} & \multirow{2}{*}{ Crude Oil } & $\mathbf{N i}$ & $17.54 \pm 0.21$ & $18.2 \pm 1$ & 95 & 96 & \multirow{2}{*}{$\begin{array}{l}\text { Souza et } \\
\text { al. (2006) }\end{array}$} \\
\hline & & $\mathbf{v}$ & $28.19 \pm 0.40$ & $27.6 \pm 0.8$ & 97 & 98 & \\
\hline \multirow{2}{*}{$\begin{array}{l}\text { HPA followed } \\
\text { by ICP-MS }\end{array}$} & \multirow{2}{*}{ Crude Oil } & $\mathbf{N i}$ & $17.54 \pm 0.21$ & $17.3 \pm 0.2$ & 99 & 99 & Ortega et \\
\hline & & $\mathbf{v}$ & $28.19 \pm 0.4$ & $29 \pm 0.4$ & 99 & 97 & al. (2013) \\
\hline
\end{tabular}

*Refer to the supplementary material (section D) for further information on how the accuracy and precision were determined. 
Table 7. Comparison of the limit of detection (LOD) of the different analytical methods used to measure the concentrations of $\mathrm{Ni}$ and $\mathrm{V}$ in crude oil standards.

\section{Limit of Detection (LOD)}

\begin{tabular}{rcc}
\hline & Ni $\left(\boldsymbol{\mu g ~ k g} \mathbf{~ k}^{-1}\right)$ & $\mathbf{V}\left(\boldsymbol{\mu g ~ \mathbf { ~ k g } ^ { - 1 } )}\right.$ \\
Current Study & 0.11 & 0.61 \\
Horeczy et al. (1955) & $\mathrm{N} / \mathrm{A}$ & $\mathrm{N} / \mathrm{A}$ \\
IP501 & 100 & 100 \\
ASTM D5708 & 1000 & 5000 \\
Duyck et al. (2002) & 0.4 & 0.02 \\
Murillo and Chirinos (1994) & 80 & 20 \\
Filby and Olsen (1994) & 100 & 50 \\
Souza et al. (2006) & 1 & 2.4 \\
Ortega et al. (2013) & N/A & N/A
\end{tabular}



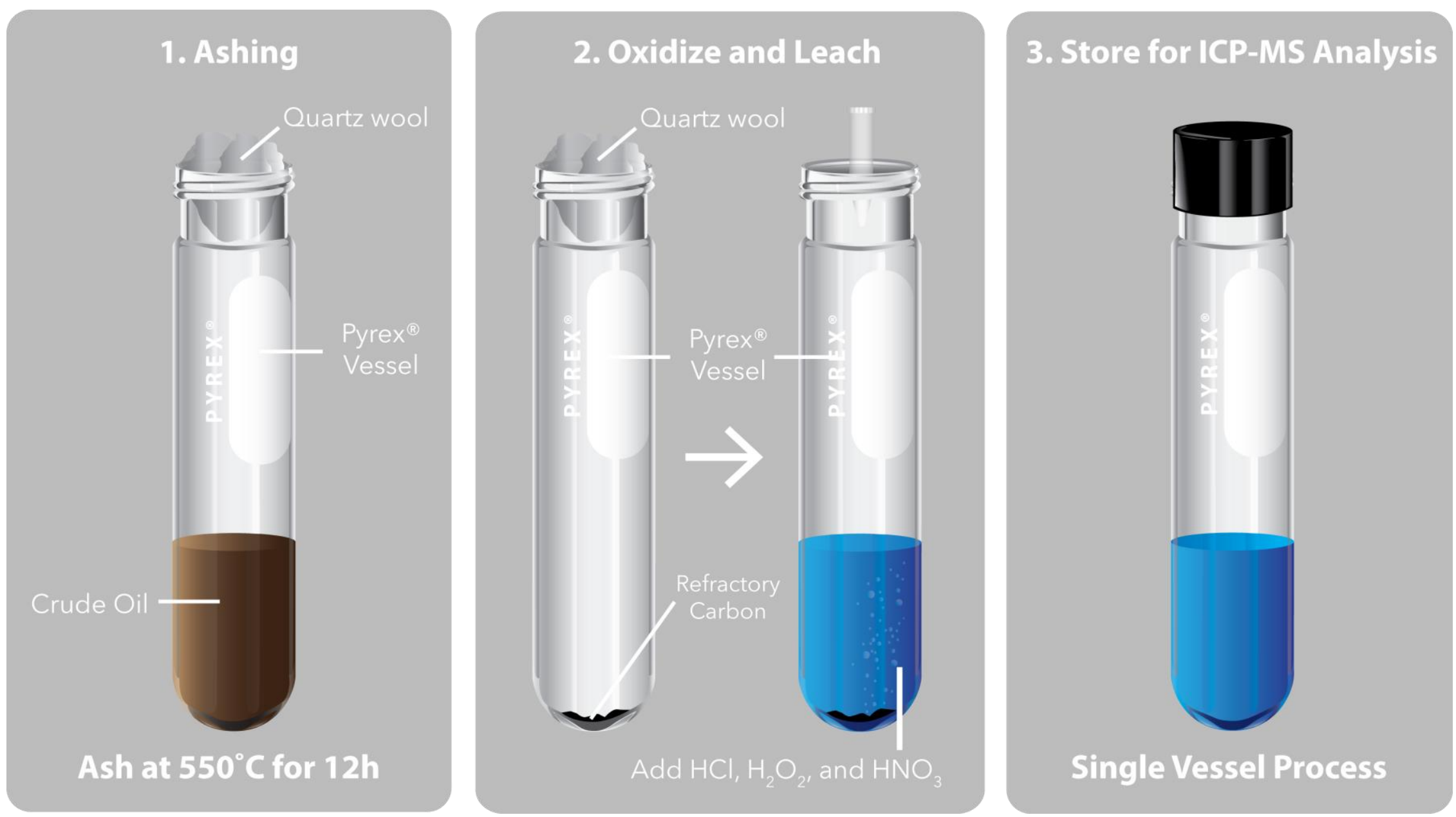

Figure 1. Sketches showing the steps employed in the ashing and chemical oxidation/acid digestion of crude oils in preparing for the analysis of their metal content by ICP-MS. Concentrations in Crude Oil." Analytica Chimica Acta 1002 (Mar 9 2018): 18-25.

http://dx.doi.org/10.1016/j.aca.2017.11.040. 

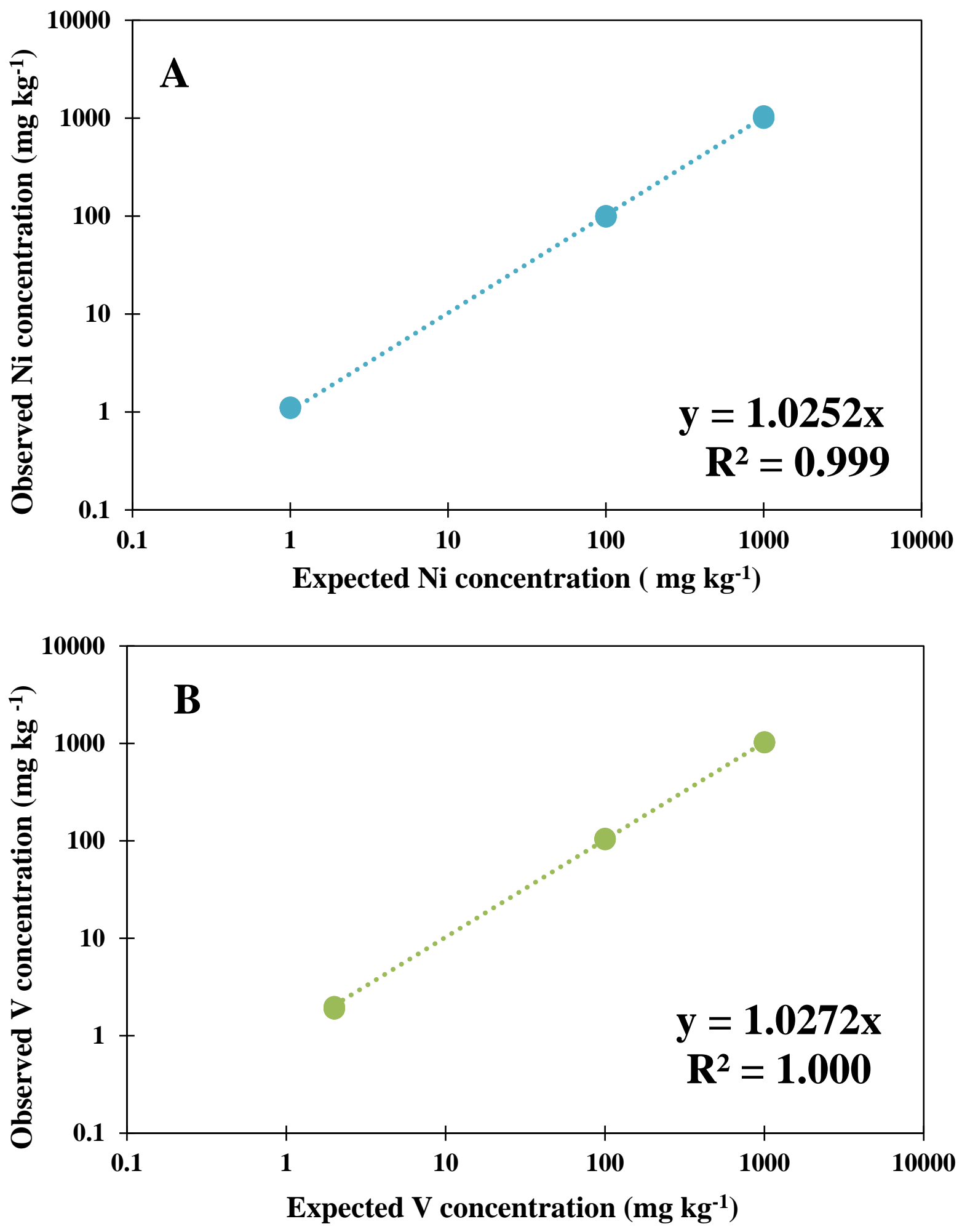

Figure 2. Diagrams showing the concentrations of $\mathrm{Ni}(\mathrm{A})$ and $\mathrm{V}(\mathrm{B})$ in oil standards measured using ICP-MS after ashing/chemical oxidation/acid digestion versus their certified concentrations. The oil standards were analyzed in quadruplicate and yielded error bars that are smaller than the data symbols. 


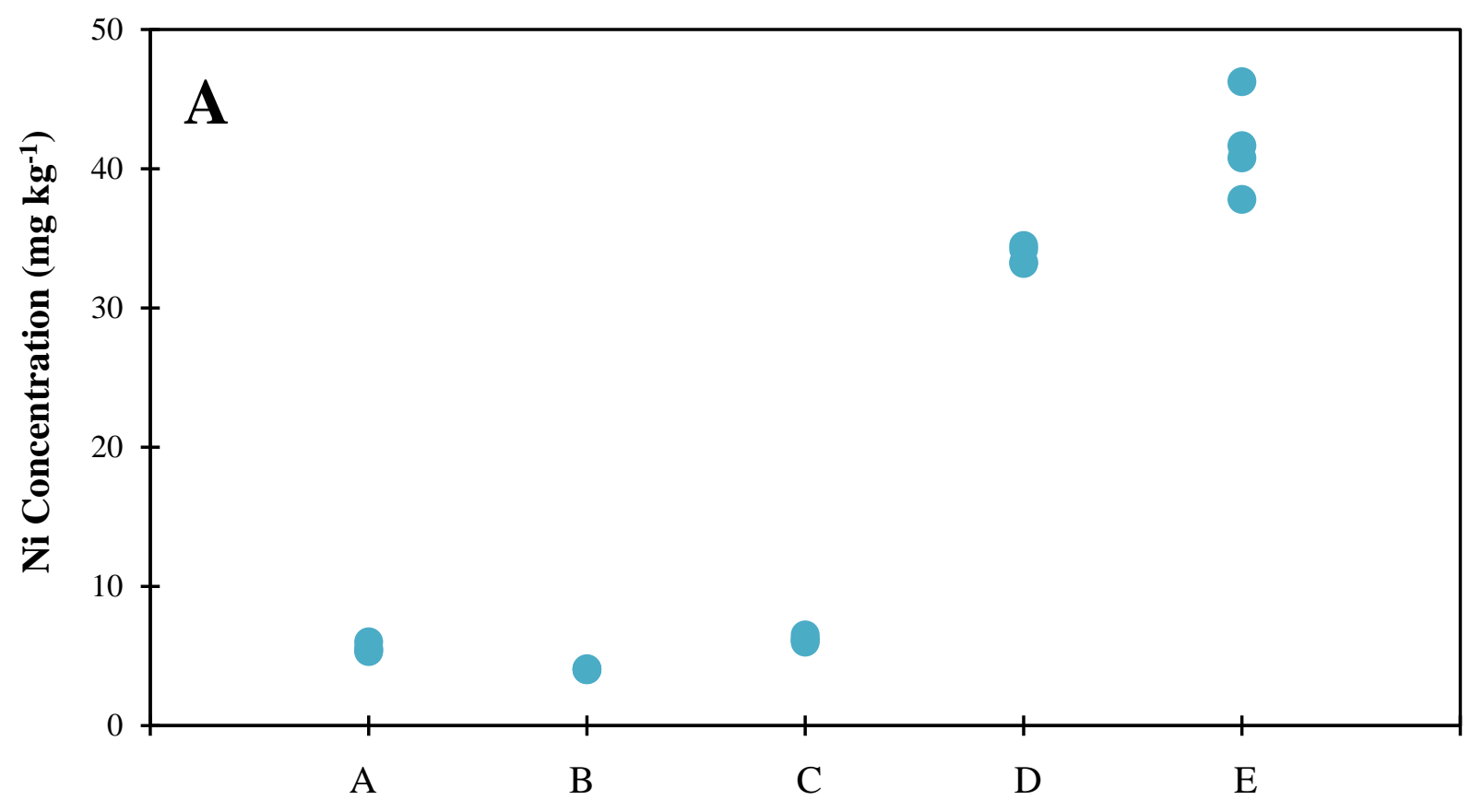

Oil Type

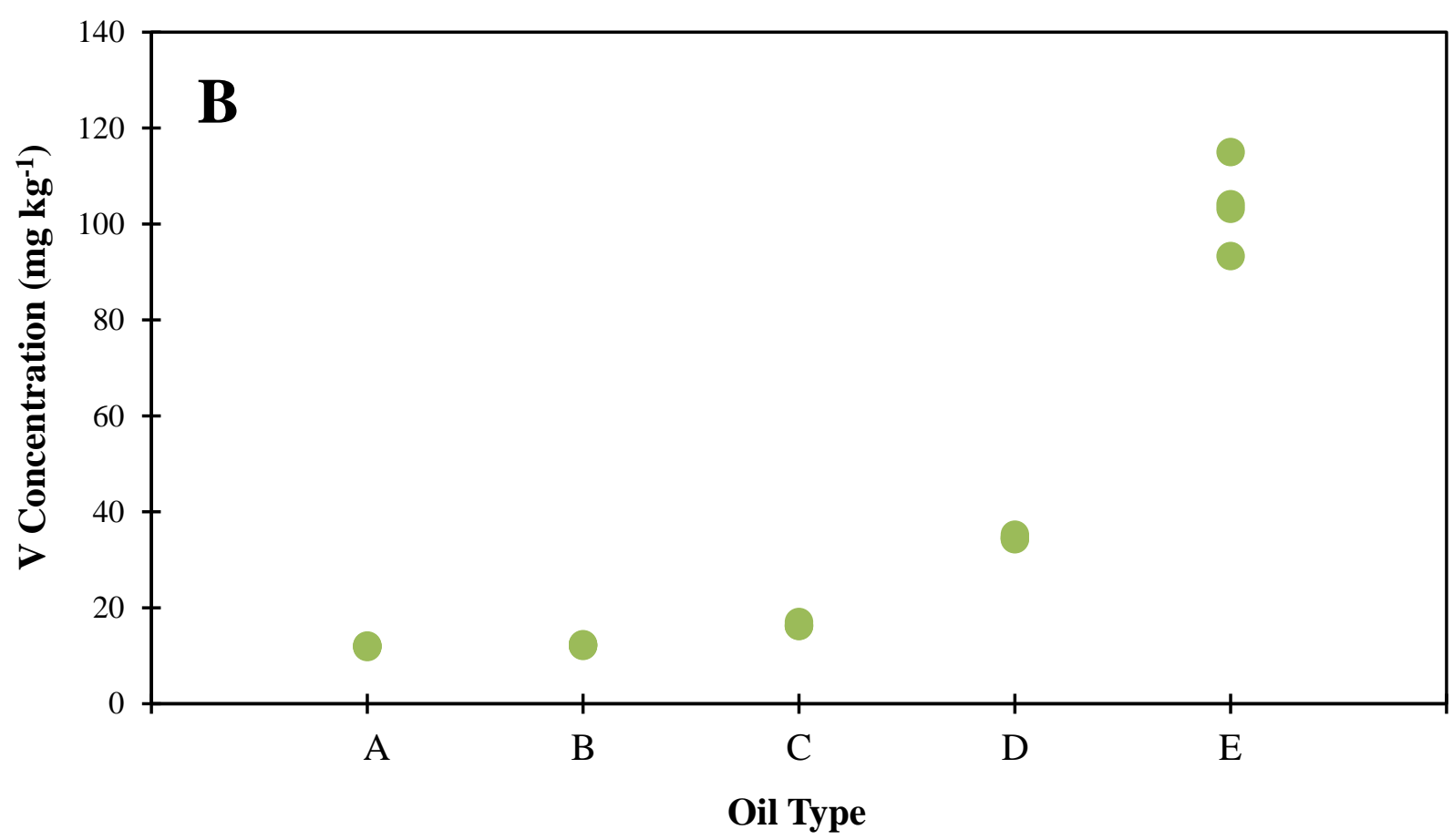

Figure 3. Diagrams showing the concentrations of $\mathrm{Ni}(\mathrm{A})$ and $\mathrm{V}$ (B) measured in five different types of crude oil A, B, C, D and E (see text for further detail). 

Accuracy Ni (\%)
- Precision Ni $(\%)$
Accuracy V (\%)
Precision V $(\%)$

Dry ashing followed by ICP-MS (Current Study)*

Dry ashing followed by ICP-MS [1]

Dry ashing followed by ICP-MS* [2]

$\leftarrow 46 \%$ Accuracy

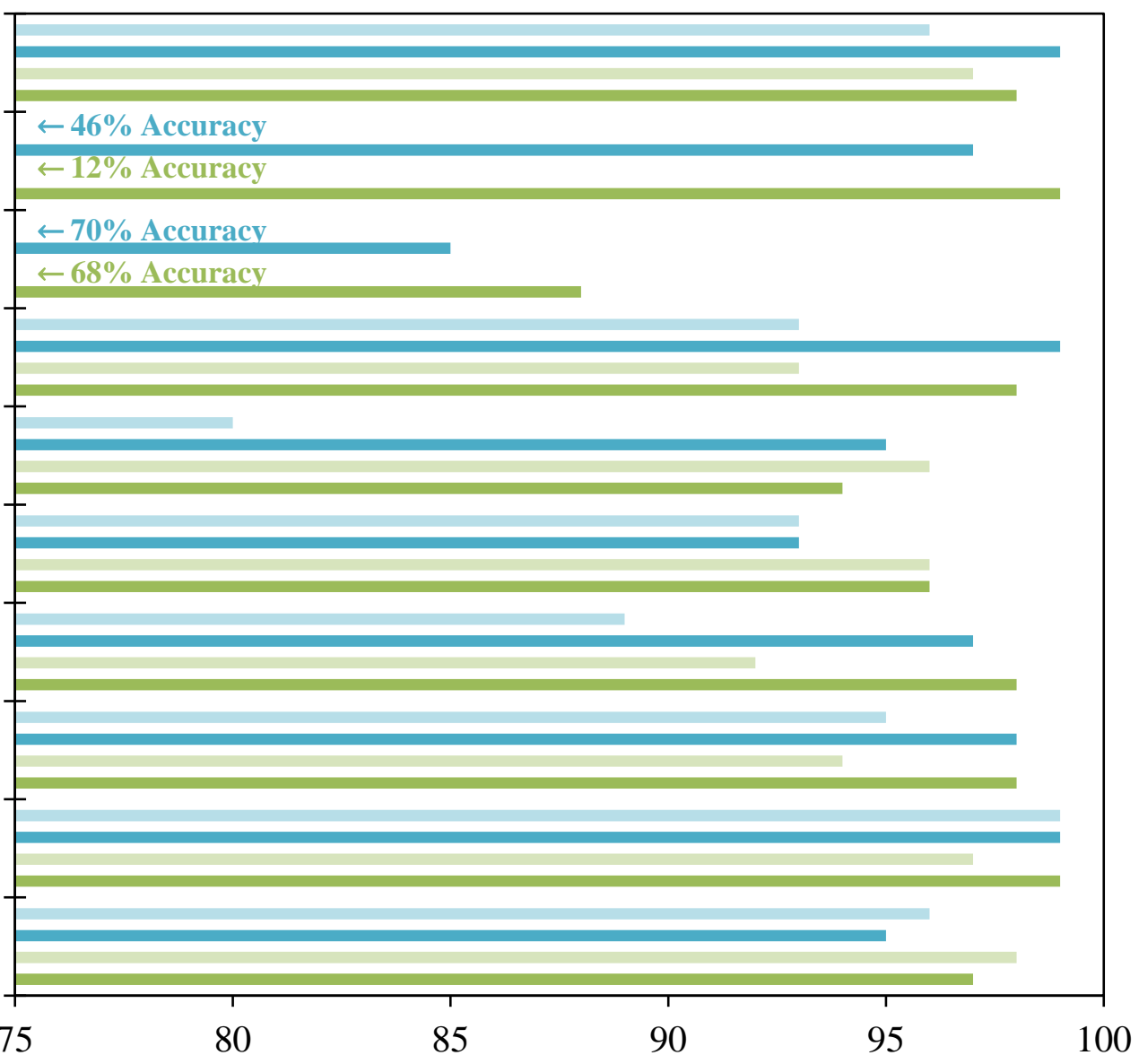

*Average values

Percent Value (\%)

Figure 4. A comparison of the accuracy and precision obtained from determining $\mathrm{Ni}$ and $\mathrm{V}$ concentrations using the various direct and indirect methods referred to in this paper (Table 6 reports the data illustrated in this figure and Section $\mathrm{C}$ of the supplementary material provides details on how the accuracy and precision were determined; [1] Horeczy et al. (1955), [2] IP 501, [3] ASTM D5708, [4] Filby and Olsen (1994), [5] Murillo and Chirinos (1994), [6] Duyck et al. (2002), [7] ASTM D5708, [8] Ortega et al. (2013), [9] Souza et al. (2006)). 
A. Tables for various techniques used to measure trace metal concentrations in hydrocarbons

Table A1. Methods used for the direct determination of trace metal concentrations in crude oil.

\section{Direct Sample Analysis}

Crude oil samples are analysed directly for their metal concentrations using the methods listed below. Commonly, in the case of methods 2, 3, 4 and 5, the oil standards and samples are diluted using toluene or are emulsified.

\section{Neutron Activation Analysis (NAA) \\ No Dilution}

2. Graphite Furnace Atomic Absorption Spectrometry (GF-AAS)

3. Inductively Coupled Plasma Mass

Spectrometry (ICP-MS)

4. Inductively Coupled Plasma Optical

Emission Spectrometry (ICP-OES)

\section{Requires dilution}

a. Organic dilution (e.g., xylene and toluene)

or

b. Emulsion of a small volume of oil in water

or

c. Emulsion of a small volume of water in oil 
Table A2. Indirect methods used to determine the concentrations of trace metals in crude oil, i.e., methods that involve the prior decomposition of the oils and the transfer of the metals to aqueous solutions.

Sample Preparation Method

\section{Wet Digestion (Destructive)}

Aliquots of acid and oil are mixed in a vessel and subjected to heat, microwaves or high pressure to digest the samples.

\section{Dry Ashing (Destructive)}

The oil initially undergoes combustion in a crucible placed in a muffled furnace oven. The refractory ash from the combustion is leached for metals using acids. 1a. High Pressure Asher (HPA)

1b. Microwave Digestion

ICP-MS, AAS or ICP-OES.

2a. Platinum Crucible and Muffled Furnace Oven

2b. Quartz Crucible and Muffled Furnace Oven
ICP-MS, AAS, or ICP-OES. 


\section{B. ICP-MS analysis: dilutions and data correction}

Prior to ICP-MS analysis, a blank solution containing $1 \mathrm{mg} \mathrm{g}^{-1} \mathrm{Y}, 2 \% \mathrm{HNO}_{3}$ and ultrapure water (Mili-Q® Integral water purification system), and a series of $\mathrm{Ni}$ and $\mathrm{V}$ aqueous standards containing $0.5,1,5,10,15,20$ and $50 \mathrm{mg} \mathrm{g}^{-1}$ of these metals were prepared. The blank solution was prepared by diluting a $1000 \mathrm{mg} \mathrm{kg}^{-1} \mathrm{Y}$ aqueous standard using trace metal grade nitric acid and ultrapure water, and the aqueous $\mathrm{Ni}$ and $\mathrm{V}$ standards by diluting a $1000 \mathrm{mg} \mathrm{kg}^{-1} \mathrm{Ni}$ and V aqueous standard with the blank solution. Both starting standards were supplied by SCP Science Ltd. The leachates were also diluted with the blank solution. The purpose of the dilution of the leachates, aqueous standards and blank solution was to minimize the suppression of analyte signals resulting from a high concentration of a matrix element during ICP-MS analysis [1]. The role of the blank solution was to act as an internal standard (Y) to monitor the stability of the instrument and to ensure that instrumental errors did not affect the results. In the case of the $\mathrm{Ni}$ and $\mathrm{V}$ oil standards, the dilution factors were $10^{2}, 10^{4}$ and $10^{5}$ times, depending on whether the metal concentrations were initially low $\left(1 \mathrm{mg} \mathrm{kg}^{-1} \mathrm{Ni}, 2 \mathrm{mg} \mathrm{kg}^{-1} \mathrm{~V}\right)$, intermediate $\left(100 \mathrm{mg} \mathrm{kg}^{-1}\right)$ or high (1000 $\mathrm{mg} \mathrm{kg}^{-1}$ ), respectively. This resulted in low $\mathrm{mg} \mathrm{g}^{-1}$ concentrations of these elements in the analyzed solutions. The leachates of crude oil samples A, B, C, D and E were diluted approximately $10^{4}$ times in the expectation that this would also result in $\mathrm{Ni}$ and $\mathrm{V}$ concentrations in the $\mathrm{mg} \mathrm{g}^{-1}$ range. All of the dilutions were conducted in centrifuge tubes, which were shaken thoroughly for a minute to homogenize the solutions. The Nickel $\left({ }^{60} \mathrm{Ni}\right)$, Vanadium $\left({ }^{51} \mathrm{~V}\right)$ and Yttrium $\left({ }^{89} \mathrm{Y}\right)$ counts of the digested acid samples (oil standards and crude oils), the $0.5,1,5,10$, 15, 20 and $50 \mathrm{mg} \mathrm{g}^{-1} \mathrm{Ni}$ and $\mathrm{V}$ aqueous standards and the blank solution $\left(1 \mathrm{mg} \mathrm{g}^{-1} \mathrm{Y}\right)$ were measured using a Thermo Fischer Scientific, Inc. iCap-Q Quadrupole ICP-MS (conditions listed in Table 2). 
The nickel $\left({ }^{60} \mathrm{Ni}\right)$ and Vanadium $\left({ }^{51} \mathrm{~V}\right)$ counts for the digested samples, the external Ni and $\mathrm{V}$ aqueous standards, and the blank solutions were converted to concentrations using the counts for ${ }^{89} \mathrm{Y}$. This involved first dividing the ${ }^{60} \mathrm{Ni}$ and ${ }^{51} \mathrm{~V}$ counts by the ${ }^{89} \mathrm{Y}$ counts to account for the instrumental fluctuation of the ICP-MS. The ${ }^{60} \mathrm{Ni} /{ }^{89} \mathrm{Y}$ and ${ }^{51} \mathrm{~V} /{ }^{89} \mathrm{Y}$ ratios for the digested samples and the aqueous standards were then subtracted from the blank ${ }^{60} \mathrm{Ni} /{ }^{89} \mathrm{Y}$ and ${ }^{51} \mathrm{~V} /{ }^{89} \mathrm{Y}$ ratios, respectively, to correct for the background ratios of the diluent. In order to convert the ${ }^{60} \mathrm{Ni}$ counts to concentrations, we constructed a calibration curve by plotting the ${ }^{60} \mathrm{Ni} /{ }^{89} \mathrm{Y}$ ratio ( $\mathrm{Y}$-axis) of the aqueous standards against the known Ni standard concentration (X-axis; Eq. B1). A calibration curve for $\mathrm{V}$ was constructed in the same way (Eq. B2). Both calibration curves regressed linearly through the origin with a goodness of fit of $99.9 \%$ (Fig. B1). Nickel and vanadium concentrations of the diluted oil standards and crude oils were calculated from the counts for the samples and the slope of the calibration curve (Eq. B3 and B4). The resulting data were corrected to obtain the undiluted concentrations using the dilution and density factor referred to in Eq. B5 and B6 (mass of a fixed volume of solution in grams divided by the mass of the same volume of sample oil in grams to account for the density differences between the analyzed solutions and the original oil standards and crude oil samples).

$$
\begin{gathered}
\left(\frac{60 N i}{89 Y}\right)_{\text {Standard }}=\text { Slope of the Calibration Curve } \times \text { Known Ni Concentration (Eq. B1) } \\
\left(\frac{51 \mathrm{~V}}{89 \mathrm{Y}}\right)_{\text {Standard }}=\text { Slope of the Calibration Curve } \times \text { Known V Concentration (Eq. B2) } \\
\mathrm{C}_{1-\mathrm{Ni}}=\text { Ni Sample Concentration }=\frac{\left(\frac{60 \mathrm{Ni}}{89 \mathrm{Y}}\right)_{\text {Sample }}}{\text { Slope of the Calibration Curve }} \text { (Eq. B3) } \\
\mathrm{C}_{1-\mathrm{V}}=\text { V Sample Concentration }=\frac{\left(\frac{51 \mathrm{~V}}{89 \mathrm{Y}}\right)_{\text {Sample }}}{\text { Slope of the Calibration Curve }} \quad \text { Eq. B4) } \\
\text { Final Ni Sample Concentration }=\mathrm{C}_{1-\mathrm{Ni}} \times \text { Dilution Factor } \times \frac{\text { Sample acid in grams }}{\text { Sample oil in grams }}(\text { Eq. B5) } \\
\text { Final V Sample Concentration }=\mathrm{C}_{1-\mathrm{V}} \times \text { Dilution Factor } \times \frac{\text { Sample acid in grams }}{\text { Sample oil in grams }}(\text { Eq. B6) }
\end{gathered}
$$



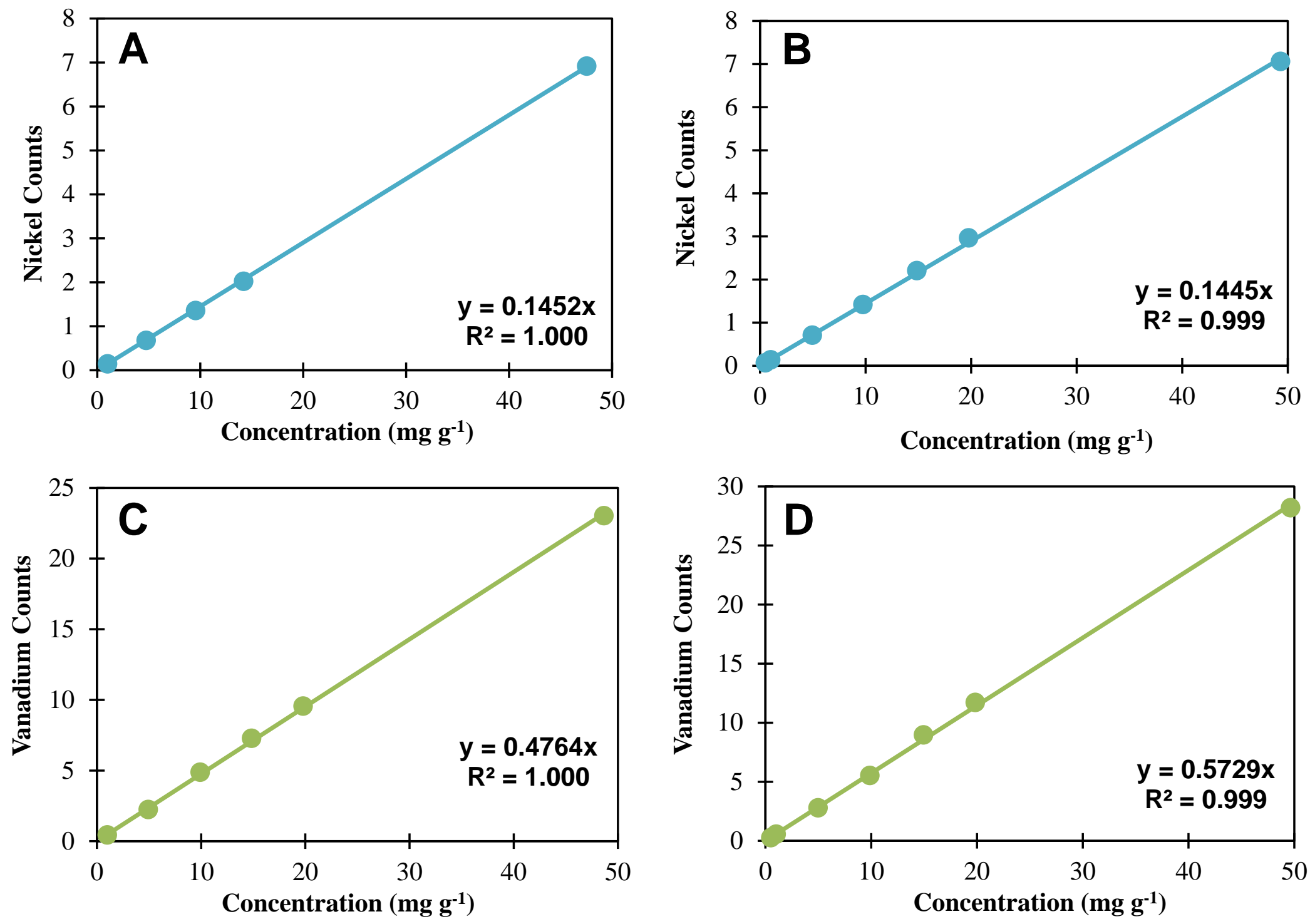

Figure B1. Diagrams illustrating the calibrations used to convert Ni and V counts into concentrations for the oil standards (A for Ni and $\mathrm{C}$ for $\mathrm{V}$ ) and the crude oil samples (B for $\mathrm{Ni}$ and $\mathrm{D}$ for $\mathrm{V}$ ). 


\section{Calculation of accuracy and precision in Table 6}

Table 6 in the main manuscript compares the accuracy and precision obtained in the present study with that published previously for a variety of methods [2-9]. These parameters were calculated in the current study as follows:

\section{C.1. Average found value}

$$
\mathbf{X}=\left(\mathbf{x}_{1}+\mathbf{x}_{2}+\ldots\right) / \mathbf{n}
$$

where $\mathbf{X}$, is the average found value, $\mathbf{x}$ is an individual measurement, and $\mathbf{n}$ is the number of samples.

\section{C.2. Precision Determination}

$$
\text { Precision }=[(\mathbf{X}-\mathbf{S D}) / \mathbf{X}] \times 100
$$

where $\mathbf{X}$ is the average found value and $\mathbf{S D}$ is the standard deviation of the found value.

For example, the precision for the $100 \mathrm{ppm}$ Ni oil standard was calculated as:

$$
\text { Precision }(100 \mathrm{ppm} \text { Ni standard })=[(99.8-1.46) / 99.8] \times 100=99 \%
$$

\section{C.3. Accuracy Determination}

$$
\text { Accuracy }=\{[\mathbf{T X}-(\mathbf{T X}-\mathbf{X})] / \mathbf{T X}\} \times 100
$$

where $\mathbf{X}$ is the average found value and TX is the average of the true certified value of the standard. For example, the precision for the $100 \mathrm{ppm} \mathrm{Ni}$ oil standard was calculated as:

$$
\text { Accuracy }(100 \text { ppm Ni standard })=\{[100-(100-99.8)] / 100\} \times 100=100 \%
$$




\section{Calculation of the Accuracy and Precision for the ASTM D4708 and IP501 Methods reported in Table 6}

\section{D.1. Definitions of Accuracy, Precision, Repeatability and Reproducibility}

Industrial sources typically measure the reliability of their results using a certified method (e.g., ASTM D5708 and IP501) by reporting the repeatability (r) and reproducibility (R) [8, 9]. In contrast, academic studies report results as the mean \pm the standard deviation for a specified number of samples and indicate the standard(s) used to test the precision and accuracy of the method. In order to make a clear comparison between results obtained using certified methods and those reported in academic journals [e.g., 2-7], it is necessary to understand the terms accuracy, precision, repeatability and reproducibility. The following are the definitions presented by Nadkarni, R. A. (2007) [10]:

Accuracy: "Measure of how close the test result will be to the true value."

Precision: "The variability between test results obtained on the same material using a specific test method."

Repeatability (r): "The "within-laboratory precision" refers to the precision of a test method when the results are obtained by the same operator in the same laboratory using the same apparatus."

Reproducibility (R): "The "between-laboratory precision" is the variability between test results obtained on aliquots of the same homogeneous material in different laboratories using the same test method."

In order to compare the accuracy and precision of the certified methods used by industry and those employed in academic studies (refer to section A of the supplementary material), we assume that precision and accuracy are equivalent to repeatability and reproducibility, respectively.

\section{D.2. Calculated repeatability and reproducibility for a certified industrial method}

Repeatability (r) and reproducibility (R) are quantified by developing empirical equations constrained by the definitions of $\mathrm{r}$ and $\mathrm{R}$ presented in D.1. using large numbers of test results. In Table B.1, we report the empirical equations for the IP501 method for Ni and use them to illustrate how the repeatability and reproducibility would be determined for a crude oil containing an average of $100 \mathrm{ppm} \mathrm{Ni}$.

Table D.1. Repeatability and reproducibility using the IP501-05 method for a crude oil containing an average of $100 \mathrm{ppm} \mathrm{Ni}$. The variable $\mathrm{X}$ represents the mean value.

\begin{tabular}{ccc} 
Nickel (Ni) & $\begin{array}{c}\text { Repeatability (r) } \\
\mathbf{~ m g / k g}\end{array}$ & $\begin{array}{c}\text { Reproducibility (R) } \\
\mathbf{~ m g / k g}\end{array}$ \\
\hline Equation & $0.8153 X^{0.55}$ & $1.6814 X^{0.55}$ \\
$\begin{array}{l}\text { Calculated value for } \\
\mathbf{1 0 0} \mathbf{~ m g / k g} \text { (average) }\end{array}$ & 10.3 & 21.1
\end{tabular}


The repeatability and reproducibility intervals presented above are based on the assumption that approximately $95 \%$ of all results will differ by less than 2.8 of the standard deviation interval. Thus, the repeatability and reproducibility intervals must be converted to the standard deviation of repeatability $\left(S_{r}\right)$ and standard deviation of reproducibility $\left(S_{R}\right)$ in order to permit comparison to precision and "accuracy", respectively. This can be done by dividing both the $\mathrm{r}$ and R by 2.8 as shown in Eq.D.1. and Eq.D.2.:

Eq.D.1. Repeatability $(\mathrm{r})=2.8 \times$ Standard deviation of Repeatability $\left(\mathrm{S}_{\mathrm{r}}\right)$

Eq.D.2. Reproducibility $(R)=2.8 \times$ Standard deviation of Reproducibility $\left(S_{R}\right)$

Using the equations presented above, we can calculate the standard deviation of both repeatability and reproducibility, as shown in Table D.2.

Table D.2. Standard deviation of repeatability and reproducibility for $100 \mathrm{mg} / \mathrm{kg} \mathrm{Ni}$.

Element

Standard deviation Repeatability (r) $\mathrm{mg} / \mathrm{kg}$
Standard deviation Reproducibility (R) $\mathrm{mg} / \mathrm{kg}$

\section{Nickel (Ni)}

3.7

7.6

Using the standard deviations of $\mathrm{r}$ and $\mathrm{R}$ and making the assumption that precision $\approx$ repeatability and accuracy $\approx$ reproducibility, the accuracy and precision of the certified method can be calculated as shown by the following example.

$$
\begin{aligned}
\text { e.g., Precision Nickel }(100 \mathrm{ppm} \text { standard }) & =[(100-3.7) / 100] \times 100=96 \% \\
\text { Accuracy Nickel }(100 \mathrm{ppm} \text { standard }) & =[(100-7.6) / 100] \times 100=92 \%
\end{aligned}
$$

Note: Results reported using certified industry methods are typically not accompanied by either the raw data or the numbers of samples that were analyzed in developing their empirical repeatability and reproducibility equations. Thus, the reliability of these results is not as easy to evaluate as it is for results published in academic journals.

In Table D.3. and Table D.4., we present the complete dataset listed for the IP501 and ASTM D5708 methods together with the calculated values of precision and accuracy used in Table 8 of our main manuscript.

Table D.3. Empirical equations used in determining the repeatability (r) and reproducibility (R) intervals for the IP501 and ASTM D5708 methods.

\begin{tabular}{cccc} 
Method & Metal & Repeatability (r) & Reproducibility (R) \\
\hline IP501 & $\mathbf{N i}$ & $0.8153 \mathrm{X}^{0.55}$ & $1.6814 \mathrm{X}^{0.55}$ \\
& $\mathbf{V}$ & $0.6549 \mathrm{X}^{0.6}$ & $1.6799 \mathrm{X}^{0.6}$ \\
ASTM D5708 (A) & $\mathbf{N i}$ & $0.01 \mathrm{X}^{1.3}$ & $0.41 \mathrm{X}^{0.78}$ \\
& $\mathbf{V}$ & $0.07 \mathrm{X}^{0.88}$ & $0.10 \mathrm{X}^{1.1}$ \\
ASTM D5708 $(\mathbf{B})$ & $\mathbf{N i}$ & $0.02 \mathrm{X}^{1.2}$ & $0.05 \mathrm{X}^{1.3}$ \\
& $\mathbf{V}$ & $0.02 \mathrm{X}^{1.1}$ & $0.10 \mathrm{X}^{1.1}$
\end{tabular}


Table D.4. The dataset used to determine repeatability, reproducibility, standard deviation of repeatability, standard deviation of reproducibility, precision and accuracy for the IP501 and ASTM D5708 methods. The equations used to generate the repeatability and reproducibility intervals are presented in Table D.3.

\begin{tabular}{|c|c|c|c|c|c|c|c|c|}
\hline Method & Metal & $\begin{array}{l}\text { "True } \\
\text { Value" } \\
(\mathbf{m g} / \mathbf{k g})\end{array}$ & $\begin{array}{c}\text { Repeatability } \\
(\mathbf{r})\end{array}$ & $\begin{array}{c}\text { Standard } \\
\text { deviation of } \\
\text { repeatability } \\
\text { (Sr) }\end{array}$ & $\begin{array}{c}\text { "Precision" } \\
(\%)\end{array}$ & $\begin{array}{l}\text { Reproducibility } \\
\text { (R) }\end{array}$ & $\begin{array}{c}\text { Standard } \\
\text { deviation of } \\
\text { reproducibility } \\
(\mathrm{SR})\end{array}$ & $\begin{array}{c}\text { "Accuracy" } \\
(\%)\end{array}$ \\
\hline IP501 & $\mathbf{N i}$ & 1 & 0.82 & 0.30 & 70 & 1.68 & 0.61 & 39 \\
\hline IP501 & $\mathbf{N i}$ & 10 & 2.89 & 1.04 & 90 & 5.97 & 2.15 & 79 \\
\hline IP501 & $\mathbf{N i}$ & 100 & 10.26 & 3.70 & 96 & 21.17 & 7.64 & 92 \\
\hline IP501 & $\mathbf{V}$ & 1 & 0.65 & 0.23 & 77 & 1.68 & 0.61 & 39 \\
\hline IP501 & $\mathbf{V}$ & 10 & 2.65 & 0.96 & 90 & 6.69 & 2.42 & 76 \\
\hline IP501 & $\mathbf{V}$ & 100 & 10.38 & 3.75 & 96 & 26.62 & 9.61 & 90 \\
\hline ASTM D5708 (A) & $\mathbf{N i}$ & 10 & 0.20 & 0.07 & 99 & 2.5 & 0.90 & 91 \\
\hline ASTM D5708 (A) & $\mathbf{N i}$ & 100 & 4.0 & 1.44 & 98 & 15 & 5.41 & 95 \\
\hline ASTM D5708 (A) & $\mathbf{V}$ & 50 & 2.2 & 0.79 & 98 & 8.9 & 3.21 & 94 \\
\hline ASTM D5708 (A) & $\mathbf{V}$ & 500 & 17 & 6.13 & 98 & 112 & 40.4 & 92 \\
\hline ASTM D5708 (B) & $\mathbf{N i}$ & 10 & 0.32 & 0.12 & 98 & 1.0 & 0.36 & 96 \\
\hline ASTM D5708 (B) & $\mathbf{N i}$ & 100 & 5.0 & 1.81 & 98 & 20 & 7.22 & 93 \\
\hline ASTM D5708 (B) & $\mathbf{V}$ & 50 & 1.5 & 0.54 & 98 & 7.4 & 2.67 & 95 \\
\hline ASTM D5708 (B) & $\mathbf{V}$ & 500 & 19 & 6.86 & 98 & 93 & 33.6 & 93 \\
\hline
\end{tabular}




\section{E. Average values for accuracy and precision presented in Figure 4}

In Figure 4 of the main manuscript, reproduced as Table E.1, we illustrate the accuracy and precision of the method developed in the current study, the IP501 method, and the ASTM method, as a bar graph. In order to simplify the figure, we used the average of the precision and accuracy values for $\mathrm{Ni}$ and $\mathrm{V}$.

Table E.1. Table 6 from the main manuscript

\begin{tabular}{|c|c|c|c|c|c|c|c|}
\hline Method & $\begin{array}{l}\text { Standard } \\
\text { Matrix }\end{array}$ & Metal & $\begin{array}{c}\text { Standard } \\
\text { Value (ppm) }\end{array}$ & $\begin{array}{c}\text { Founded } \\
\text { Value } \\
\text { (ppm) }\end{array}$ & $\begin{array}{c}\text { Precision } \\
(\%)\end{array}$ & $\begin{array}{c}\text { Accuracy } \\
(\%)\end{array}$ & Reference \\
\hline \multirow{6}{*}{$\begin{array}{l}\text { Dry Ashing } \\
\text { followed by } \\
\text { ICP-MS }\end{array}$} & \multirow{6}{*}{ Crude Oil } & $\mathrm{Ni}$ & 1 & $1.1 \pm 0.01$ & 99 & 90 & \multirow{6}{*}{$\begin{array}{l}\text { Current } \\
\text { Study }\end{array}$} \\
\hline & & $\mathrm{Ni}$ & 100 & $99.8 \pm 1.46$ & 99 & 100 & \\
\hline & & $\mathrm{Ni}$ & 1000 & $1025 \pm 24$ & 98 & 98 & \\
\hline & & $\mathbf{v}$ & 2 & $1.93 \pm 0.06$ & 97 & 97 & \\
\hline & & v & 100 & $104 \pm 1.3$ & 99 & 96 & \\
\hline & & v & 1000 & $1027 \pm 7.5$ & 99 & 97 & \\
\hline
\end{tabular}

The precision and accuracy values for the concentrations of the 1, 100 and 1000 ppm Ni standards were combined into a single averaged value as follows:

$$
\begin{gathered}
\text { Average precision for } \mathrm{Ni}=(99+99+98) / 3=99 \% \\
\text { Average accuracy for } \mathrm{Ni}=(90+100+98) / 3=96 \%
\end{gathered}
$$

This calculation was only conducted for the method developed in our current study, the IP 501 method, and the ASTM D5708 method. 
F. Method Validation: limit of detection (LOD), limit of quantification (LOQ), instrumental detection limit (IDL), precision, accuracy, working range, linearity, selectivity, and stability

Table F.1. Parameters for method validation for our current study (limit of detection (LOD), limit of Quantification (LOQ), instrumental detection limit (IDL), precision, accuracy, working range, and linearity) are listed below.

\begin{tabular}{rcc} 
Method Validation & ${ }^{\mathbf{6 0}} \mathbf{N i}$ & ${ }^{\mathbf{5 1}} \mathbf{V}$ \\
\hline Working Range $\left(\mathbf{m g ~ k g}^{-\mathbf{1}}\right)$ & $0.0004-1000$ & $0.0020-1000$ \\
$\mathbf{L O D}\left(\boldsymbol{\mu} \mathbf{~ k g}^{-\mathbf{1}}\right)$ & 0.11 & 0.61 \\
$\mathbf{L O Q}\left(\boldsymbol{\mu g} \mathbf{~ k g}^{-\mathbf{1}}\right)$ & 0.37 & 2.03 \\
$\mathbf{I D L}\left(\boldsymbol{\mu g} \mathbf{~ k g}^{-\mathbf{1}}\right)$ & 0.005 & 0.006 \\
Precision* $(\boldsymbol{\%})$ & 99 & 98 \\
Accuracy* $(\boldsymbol{\%})$ & 96 & 97 \\
Linearity $(\boldsymbol{\%})$ & 99.9 & 100
\end{tabular}

\section{F.1. Limit of Detection (LOD) and Limit of Quantification (LOQ)}

The limit of detection (LOD) was calculated using the following relationship:

$$
\text { LOD }=\left[\left(3 \sigma_{\text {blank }}\right) / \text { Slope }\right] \times \text { DF }
$$

- $3 \sigma_{\text {blank: }}$ Oblank represents the precision of the blank (for Ni and V). The $\sigma_{\text {blank value is }}$ multiplied by $3 x$ to give a $99 \%$ confidence on the error.

- Slope: slope of the calibration curve used for this study

- DF: dilution factor of our methodology

Note: Table 7 in our main manuscript used the above equation to calculate the LOD. We compare our LOD with those for various other methods in section 4.1 of our main manuscript.

The limit of quantification (LOQ) was calculated using the following relationship:

$$
\mathrm{LOQ}=\left[\left(10 \sigma_{\text {blank }}\right) / \text { Slope }\right] \times \mathrm{DF}
$$

- $10 \sigma_{\text {blank }}$ : $\sigma_{\text {blank }}$ represents the precision of the blank (for Ni and V). The $\sigma_{\text {blank value is }}$ multiplied by $10 \mathrm{x}$ to give the minimum quantifiable value that is $10 \mathrm{x}$ the background signal.

- Slope: slope of the calibration curve used for this study

- DF: dilution factor of our methodology

\section{F.2. Instrumental detection limit (IDL)}


Instrumental detection limit (IDL) is the detection limit of the instrument, Thermo Scientific ${ }^{\mathrm{TM}}$ iCAPTM Q ICP-MS, used in our study. The calibration curve for ${ }^{60} \mathrm{Ni}$ and ${ }^{51} \mathrm{~V}$ isotopes regressed linearly with $r^{2}$ value $\geq 99.9 \%$. ICP-MS is the preferred instrument for accurate measurement of analytes $<1 \mathrm{mg} \mathrm{kg}^{-1}$.

\section{F.3. Precision and Accuracy}

Please refer to section 4.1 of the main manuscript and appendix $\mathrm{C}$ for more information.

\section{F.4. Linearity of our ashing-chemical oxidation-acid digestion-ICP-MS Method}
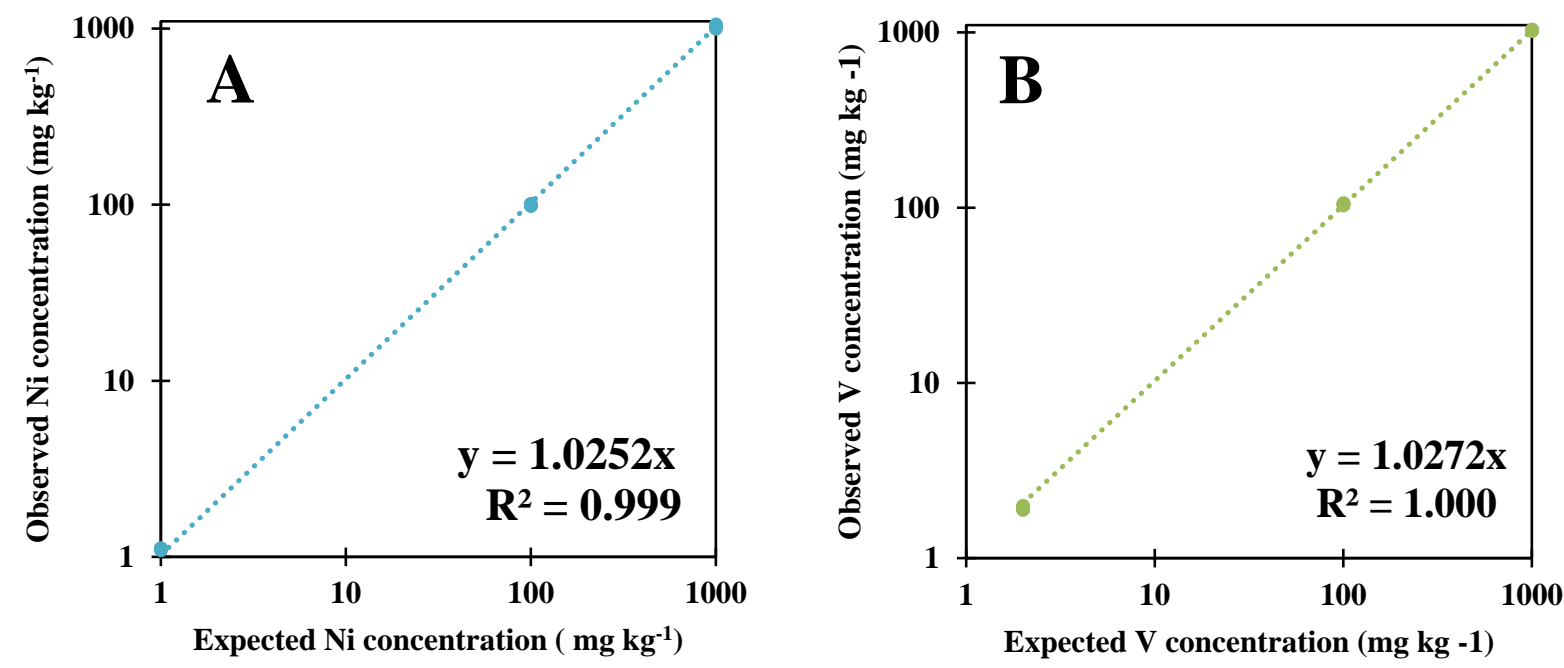

Figure F1. The linearity of Ni (A) and V (B) for crude oil standards using our ashing-chemical oxidation-acid digestion-ICP-MS method.

The linearity for Ni (A) and V (B) using our proposed method is 99.9 and 100\%, respectively, and the slope is 1.0252 and 1.0272, respectively. As the slope did not exceed the range of 0.9 to 1.1 and the goodness of fit was $\geq 99.9 \%$, our observed trace metal concentrations (i.e., Ni and V) showed excellent agreement with the expected metal concentration in crude oil standards.

\section{F.5. Stability}

Typically, under acidic conditions, metals are stable in aqueous media for at least a year (e.g., ICPMS standards). We can confirm that our sample shelf life is at least 17 days.

\section{F.5. Selectivity}

Our ashing-chemical oxidation-acid digestion-ICP-MS method is non-selective, and produces accurate results for $\mathrm{Ni}$ and $\mathrm{V}$ concentrations for a wide range of crude oil compositions.

\section{G. Conostan Standards}




\section{APPENDIX}

Conostan standard certificates are presented in the pages that follow. 


\section{CONOST $\triangle^{\circ}$ Oil Analysis Standards}

Manufactured by SCP SCIENCE 21800 Clark Graham, Baie d'Urfé (Montreal) Quebec, Canada H9X 4B6

Tel: 1-514-457-0701/1-(800) 361-6820

\section{Certificate of Analysis}

\subsection{DESCRIPTION: CONOSTAN Custom Blend Single Element Standard}

$\mathrm{Ni}:$ 1ppm;

Catalogue Number: CB7-100-002

Lot Number: $\quad$ 130130-8

Matrix: $\quad$ Crude oil

Expiration Date: $\mathbf{1 2}$ months from date of shipment (see bottle for date of shipment)

\subsection{CERTIFIED VALUES AND ASSOCIATED UNCERTAINTY, $\mu \mathrm{g} / \mathrm{g}$}

Method of analysis and traceability:

\section{$\mathrm{Ni}$}

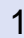

This standard was prepared by weight measurements originating from assayed element Concentrates. Element concentrations for this standard are based on the Concentrate assay* values and were determined by weight measurements of blend components conducted on balances calibrated and verified with NIST traceable weights. The uncertainty of the stated value has not been determined for concentrations < 3ppm.

*Each element Concentrate was assayed by classical wet chemical methods. Precision of assay measurement is \pm 0.5 percent maximum, but typically \pm 0.3 percent, or less. Assay accuracy is within one percent of measured value, but typically much less, as determined by comeasurement of, and traceability to, NIST Standards, or Certified Analytical Reagent Grade Chemicals, if no suitable NIST standards exists.

\subsection{REFERENCE VALUES:}

None

\subsection{APPROVAL AND DATE OF CERTIFICATION:}

Certification Date:

Certification Approval:
January 30,2013

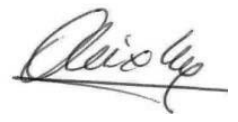

Alketa Mixha

Conostan Production Manager 


\section{CONOST ${ }^{\circ} N^{\circ}$ Oil Analysis Standards}

Manufactured by SCP SCIENCE 21800 Clark Graham, Baie d'Urfé (Montreal) Quebec, Canada H9X 4B6

Tel: 1-514-457-0701/1-(800) 361-6820

\section{Certificate of Analysis}

\subsection{DESCRIPTION: CONOSTAN Custom Blend Mono-Element Standard}

\section{Ni: 100ppm;}

Catalogue Number: CB7-100-018

Lot Number: $\quad$ 140130-10

Matrix:

Crude oil

Expiration Date: 12 months from date of shipment (see bottle for date of shipment)

\subsection{CERTIFIED VALUES AND ASSOCIATED UNCERTAINTY, $\mu \mathrm{g} / \mathrm{g}$}

Method of analysis and traceability:
$\mathrm{Ni}$

100

\subsection{REFERENCE VALUES:}

This standard was prepared by weight measurements originating from assayed element Concentrates. Element concentrations for this standard are based on the Concentrate assay* values and were prepared to within \pm 2.0 percent relative or better as determined by weight measurements of blend components conducted on balances calibrated and verified with NIST traceable weights.

*Each element Concentrate was assayed by classical wet chemical methods. Precision of assay measurement is \pm 0.5 percent maximum, but typically \pm 0.3 percent, or less. Assay accuracy is within one percent of measured value, but typically much less, as determined by comeasurement of, and traceability to, NIST Standards, or Certified Analytical Reagent Grade Chemicals, if no suitable NIST standards exists.

None

\subsection{APPROVAL AND DATE OF CERTIFICATION:}

Certification Date:

Certification Approval:
January 30,2014

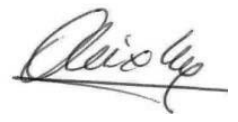

Alketa Mixha

Conostan Production Manager 


\section{CONOSTAN \\ Oil Analysis Standards}

Manufactured by SCP SCIENCE 21800 Clark Graham, Baie d'Urfé (Montreal)

Quebec, Canada H9X 4B6
Tel: 1-514-457-0701 / 1-(800) 361-6820

\section{Certificate of Analysis}

\subsection{DESCRIPTION: CONOSTAN Custom Blend Single Element Standard}

Catalogue Number:

$$
\text { Ni: 1000ppm; }
$$

Lot Number:

CB7-100-019

Matrix:

140130-11

Expiration Date:

Crude oil

12 months from date of shipment (see bottle for date of shipment)

\subsection{CERTIFIED VALUES AND ASSOCIATED UNCERTAINTY, $\mu \mathrm{g} / \mathrm{g}$}

Method of analysis and traceability:

\begin{abstract}
This standard was prepared by weight measurements originating from assayed element Concentrates. Element concentrations for this standard are based on the Concentrate assay* values and were prepared to within \pm 2.0 percent relative or better as determined by weight measurements of blend components conducted on balances calibrated and verified with NIST traceable weights.

*Each element Concentrate was assayed by classical wet chemical methods. Precision of assay measurement is \pm 0.5 percent maximum, but typically \pm 0.3 percent, or less. Assay accuracy is within one percent of measured value, but typically much less, as determined by comeasurement of, and traceability to, NIST Standards, or Certified Analytical Reagent Grade Chemicals, if no suitable NIST standards exists.
\end{abstract}

\subsection{REFERENCE VALUES:}

None

\subsection{APPROVAL AND DATE OF CERTIFICATION:}

Certification Date:

January 30,2014

Certification Approval:

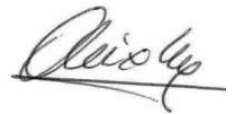

Alketa Mixha

Conostan Production Manager 


\section{CONOST $\triangle^{\circ}$ Oil Analysis Standards}

Manufactured by SCP SCIENCE 21800 Clark Graham, Baie d'Urfé (Montreal) Quebec, Canada H9X 4B6

Tel: 1-514-457-0701/1-(800) 361-6820

\section{Certificate of Analysis}

1.0 DESCRIPTION: CONOSTAN Custom Blend Single Element Standard

Catalogue Number: V: 2ppm (Crude oil);

Lot Number:

CB7-100-024

Matrix:

140506-30

Expiration Date:

Crude oil

12 months from date of shipment (see bottle for date of shipment)

\subsection{CERTIFIED VALUES AND ASSOCIATED UNCERTAINTY, $\mu \mathrm{g} / \mathrm{g}$}

Method of analysis and traceability:
$\mathrm{V}$

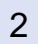

\subsection{REFERENCE VALUES:}

This standard was prepared by weight measurements originating from assayed element Concentrates. Element concentrations for this standard are based on the Concentrate assay* values and were determined by weight measurements of blend components conducted on balances calibrated and verified with NIST traceable weights. The uncertainty of the stated value has not been determined for concentrations < 3ppm.

*Each element Concentrate was assayed by classical wet chemical methods. Precision of assay measurement is \pm 0.5 percent maximum, but typically \pm 0.3 percent, or less. Assay accuracy is within one percent of measured value, but typically much less, as determined by comeasurement of, and traceability to, NIST Standards, or Certified Analytical Reagent Grade Chemicals, if no suitable NIST standards exists.

None

\subsection{APPROVAL AND DATE OF CERTIFICATION:}

Certification Date:

Certification Approval:
May 07,2014

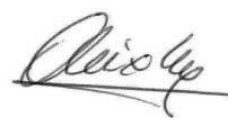

Alketa Mixha

Conostan Production Manager 


\section{CONOST ${ }^{\circ} N^{\circ}$ Oil Analysis Standards}

Manufactured by SCP SCIENCE 21800 Clark Graham, Baie d'Urfé (Montreal) Quebec, Canada H9X 4B6

Tel: 1-514-457-0701/1-(800) 361-6820

\section{Certificate of Analysis}

\subsection{DESCRIPTION: CONOSTAN Custom Blend Mono-Element Standard}

\section{V: 100ppm;}

Catalogue Number: CB7-100-025

Lot Number: $\quad$ 140506-31

Matrix: $\quad$ Crude oil

Expiration Date: $\mathbf{1 2}$ months from date of shipment (see bottle for date of shipment)

\subsection{CERTIFIED VALUES AND ASSOCIATED UNCERTAINTY, $\mu \mathrm{g} / \mathrm{g}$}

Method of analysis and traceability:
V

100

\subsection{REFERENCE VALUES:}

This standard was prepared by weight measurements originating from assayed element Concentrates. Element concentrations for this standard are based on the Concentrate assay* values and were prepared to within \pm 2.0 percent relative or better as determined by weight measurements of blend components conducted on balances calibrated and verified with NIST traceable weights.

*Each element Concentrate was assayed by classical wet chemical methods. Precision of assay measurement is \pm 0.5 percent maximum, but typically \pm 0.3 percent, or less. Assay accuracy is within one percent of measured value, but typically much less, as determined by comeasurement of, and traceability to, NIST Standards, or Certified Analytical Reagent Grade Chemicals, if no suitable NIST standards exists.

None

\subsection{APPROVAL AND DATE OF CERTIFICATION:}

Certification Date:

Certification Approval:
May 07,2014

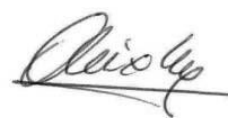

Alketa Mixha

Conostan Production Manager 


\section{CONOSTAS \\ Oil Analysis Standards}

Manufactured by SCP SCIENCE 21800 Clark Graham, Baie d'Urfé (Montreal) Quebec, Canada H9X 4B6

Tel: $1-514-457-0701 / 1-(800) 361-6820$

\section{Certificate of Analysis}

\subsection{DESCRIPTION: CONOSTAN Custom Blend Single Element Standard}

V: 1000ppm;

Catalogue Number: CB7-100-026

Lot Number: $\quad$ 140506-32

Matrix:

Expiration Date:

Base Oil $75 \mathrm{cSt}$

12 months from date of shipment (see bottle for date of shipment)

\subsection{CERTIFIED VALUES AND ASSOCIATED UNCERTAINTY, $\mu \mathrm{g} / \mathrm{g}$}

Method of analysis and traceability:

\begin{abstract}
This standard was prepared by weight measurements originating from assayed element Concentrates. Element concentrations for this standard are based on the Concentrate assay* values and were prepared to within \pm 2.0 percent relative or better as determined by weight measurements of blend components conducted on balances calibrated and verified with NIST traceable weights.

*Each element Concentrate was assayed by classical wet chemical methods. Precision of assay measurement is \pm 0.5 percent maximum, but typically \pm 0.3 percent, or less. Assay accuracy is within one percent of measured value, but typically much less, as determined by comeasurement of, and traceability to, NIST Standards, or Certified Analytical Reagent Grade
\end{abstract} Chemicals, if no suitable NIST standards exists.

\subsection{REFERENCE VALUES:}

None

\subsection{APPROVAL AND DATE OF CERTIFICATION:}

Certification Date:

May 7, 2014

Certification Approval:

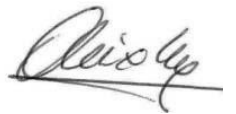

Alketa Mixha

Conostan Production Manager 


\section{References}

[1] Thomas, R. (2013). Practical guide to ICP-MS: a tutorial for beginners. CRC press.

[2] Duyck, C., Miekeley, N., da Silveira, C. L. P., \& Szatmari, P. (2002). Trace element determination in crude oil and its fractions by inductively coupled plasma mass spectrometry using ultrasonic nebulization of toluene solutions. Spectrochimica Acta Part B: Atomic Spectroscopy, 57(12), 1979-1990.

[3] Filby, R., \& Olsen, S. (1994). A comparison of instrumental neutron activation analysis and inductively coupled plasma-mass spectrometry for trace element determination in petroleum geochemistry. Journal of radioanalytical and nuclear chemistry, 180(2), 285-294.

[4] Horeczy, J. T., Hill, B. N., Walters, A. E., Schutze, H. G., \& Bonner, W. H. (1955). Determination of trace metals in oils. Analytical Chemistry, 27(12), 1899-1903.

[5] Murillo, M., \& Chirinos, J. (1994). Use of emulsion systems for the determination of sulfur, nickel and vanadium in heavy crude oil samples by inductively coupled plasma atomic emission spectrometry. Journal of Analytical Atomic Spectrometry, 9(3), 237-240.

[6] Ortega, G. S., Pécheyran, C., Hudin, G., Marosits, E., \& Donard, O. F. (2013). Different approaches of crude oil mineralisation for trace metal analysis by ICPMS. Microchemical Journal, 106, 250-254.

[7] de Souza, R. M., Meliande, A. L., da Silveira, C. L., \& Aucélio, R. Q. (2006). Determination of $\mathrm{Mo}, \mathrm{Zn}, \mathrm{Cd}, \mathrm{Ti}, \mathrm{Ni}, \mathrm{V}, \mathrm{Fe}, \mathrm{Mn}, \mathrm{Cr}$ and $\mathrm{Co}$ in crude oil using inductively coupled plasma optical emission spectrometry and sample introduction as detergentless microemulsions. Microchemical Journal, 82(2), 137-141.

[8] EI-IP, 501-2005. Determination of aluminium, silicon, vanadium, nickel, iron, sodium, calcium, zinc and phosphorus in residual fuel oil by ashing, fusion and inductively coupled plasma emission spectrometry.

[9] ASTM Standard D5708, 2005e15, " Standard Test Methods for Determination of Nickel, Vanadium, and Iron in Crude Oils and Residual Fuels by Inductively Coupled PlasmaAtomic Emission Spectrometry," ASTM International, West Conshohocken, PA.

[10] Nadkarni, R. A. (2007). Guide to ASTM test methods for the analysis of petroleum products and lubricants. ASTM International, West Conshohocken, PA. 